ROCZNIKI FILOZOFICZNE

Tom LXIX, numer $4-2021$

DOI: http://doi.org/10.18290/rf21694-15

\title{
ADAM JONKISZ
}

\section{LOGICZNE UJĘCIE PYTAŃ I ODPOWIEDZI. UWAGI MERYTORYCZNE I METODOLOGICZNE}

Zawarte w artykule uwagi odnoszą się do wypowiedzi Profesorów Anny Brożek, Marka Lechniaka i Jacka Wojtysiaka, dotyczących ujęcia, które przedstawiłem w monografii Pytania i odpowiedzi. Ujęcie teoriomnogościowe (=JoNKISZ 2020) ${ }^{1}$. Sformułowane w tych wypowiedziach komentarze i propozycje ulepszeń odnoszą się do koncepcji pytań i odpowiedzi lub do stosowanego w monografii sposobu ich analizowania i rekonstruowania oraz formułowania, uzasadniania i porządkowania twierdzeń składających się na tę koncepcję. Odpowiednio do tego również w niniejszym artykule odpowiedzi są podzielone na merytoryczne i metodologiczne ${ }^{2}$.

Prof. dr hab. ADAm JonKISZ - Akademia Ignatianum w Krakowie, Wydział Filozoficzny, Instytut Filozofii, Katedra Logiki, Epistemologii i Filozofii Nauki; adres do korespondencji: ul. Kopernika 26, 31-501 Kraków; e-mail: adam.jonkisz@ignatianum.edu.pl; ORCID: https://orcid.org/ 0000-0001-9850-2137.

${ }^{1}$ Wypowiedzi opublikowane w niniejszym tomie Roczników Filozoficznych (BrożEK 2021, 259-280; LechNiaK 2021, 281-303; WoJTysiaK 2021, 305-314). Odnosząc się do tych wypowiedzi ogólnie, będę mówił o (głosach w naszej, tej) dyskusji, a odsyłając do tej książki - o monografii (zawartych w niej rozwiązaniach, propozycjach, definicjach etc.).

${ }^{2}$ Podział na kwestie merytoryczne vs metodologiczne - ogólnie względny i nieostry — jest przeprowadzony według tego, czy dotyczą one koncepcji pytań i odpowiedzi, czy metod uzasadniania jej twierdzeń, choć uwagi co do metod mogą być merytoryczne w tym znaczeniu, że dotykają podstaw stosowanej metody, np. sposobu reprezentowania osnowy pytania i jej składników. W tekście niemalże zupełnie nie odnoszę się do komentarzy i uzupełnień historycznych - sformułowanych w wypowiedziach publikowanych w niniejszym tomie oraz w dyskusji bezpośredniej (zwłaszcza przez prof. M. Rembierza) — odsyłających przede wszystkim do filozofii i erotetyki polskiej (wzmianki o innych osiągnięciach, w tym o ważnych dla dzisiejszych teorii pytań, są w artykułach J. Wojtysiaka i M. Lechniaka). Uwagi historyczne są cennym uzupełnieniem, a niekiedy także sprawdzianem wyników badań takich, jak przedstawione w monografii. Dziękuję za nie uczestnikom dyskusji — i tak jedynie mogę na nie odpowiedzieć, ponieważ nie potrafię, nie tylko w tym tekście, odnieść się do nich merytorycznie. 


\section{A. KWESTIE MERYTORYCZNE}

Poruszone w wypowiedziach kwestie merytoryczne można podzielić rezygnując z warunków wyczerpywania i ostrości - na dotyczące struktury, rodzajów i trafności pytań.

\section{A.1 Schemat POLSKI}

Przedstawione w monografii rozwiązania są zgodne ze schematem struktury pytań zwanym polskim, przypomnianym w naszej dyskusji przez prof. Annę Brożek. Chodzi o formułę

$[? x] P(x)$,

którą w 1926 r. zaproponował K. Ajdukiewicz w autoreferacie „Analiza semantyczna zdania pytajnego", ilustrując jej trafność kilkoma przykładami pytań do uzupełnienia ${ }^{3}$. Rozwiązania te zawierają jednak ważne uzupełnienie schematu zaproponowanego przez Ajdukiewicza i poprawianego przez nawiązujących do jego koncepcji. Chodzi o zrekonstruowanie w samym schemacie tzw. przedmiotu pytania, tj. uwzględnienie w nim uniwersum, w którym mieszczą się możliwości wskazywane w odpowiedziach na pytanie zwanych właściwymi, a odsyłające do nich wyrażenia są podstawiane za zmienną (zmienne) w schemacie odpowiedzi.

Dla potrzeb naszej dyskusji warto przypomnieć uzasadniony $\mathrm{w}$ monografii, ogólny schemat struktury pytań:

$(*) ? x^{*}$ in $U^{*}: C^{*}\left(x^{*}\right)$.

Jak widać, w schematach „polskim” i (*) odpowiadają sobie człony „,? $[$ ]” $\mathrm{i},, ? x^{*}$ in $U^{*}$ :” oraz , $P(x)$ ” i „, $C^{*}\left(x^{*}\right) ”$. Już porównanie samego kształtu

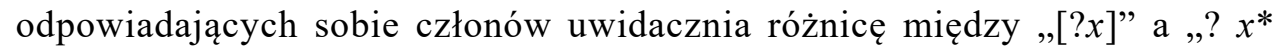
in $U^{*}$ :" Pierwszy człon schematu (*) wskazuje na tzw. przedmiot pytania, tj. nie tylko, jak w schemacie ,polskim”, na jego niewiadomą, lecz na uniwersum i odpowiednią dlań niewiadomą. Uzupełnienie to jest ważne, daje bowiem możliwość uściślania i ujednoznaczniania zdań pytajnych. Zdania pytajne bowiem mogą być potencjalnie wieloznaczne i pod względem tego, co w danym pytaniu jest zakładane (przyjmowane, dane), a co jest kwestionowane (czego pytanie dotyczy, co jest jego niewiadomą), jak i wielo-

\footnotetext{
${ }^{3} \mathrm{Na}$ ten schemat i jego źródło zwróciła moją uwagę A. Brożek w recenzji wydawniczej monografii.
} 
znaczne pod względem tzw. kwantyfikacji, tj. tego, ile możliwości z zakresu niewiadomej trzeba wskazać, odpowiadając na pytanie ${ }^{4}$.

Pod $(*)$ podpadają schematy struktury wszystkich tradycyjnie wyróżnianych rodzajów pytań: pytań do rozstrzygnięcia, do wyjaśnienia (problemowych) i do uzupełnienia. Pytania tych rodzajów również w monografii są odrębnie analizowane, a przy tym najpierw jest rozważana potencjalna wieloznaczność zdań pytajnych, a następnie - w wyniku analiz dotyczących różnorodnych pytań każdego z tych rodzajów - są zaproponowane takie schematy struktury dla pytań tych kategorii (i ich podkategorii), w których da się uwzględnić tę potencjalną wieloznaczność, tj. da się wskazać w schemacie na to znaczenie zdania pytajnego, w którym jest ono (może być) wzięte w konkretnej sytuacji pytajnej ${ }^{5}$.

\section{SKŁADNIKI OSNOWY KWESTIONOWANE VS ZAKŁADANE}

Pominąwszy chwilowo sprawę tzw. kwantyfikacji pytania, można przyjąć, że schematy podstawowe dla tych kategorii pytań to:

$(*)_{\mathrm{R}} \quad ? x \in\{\{\ldots\}, \operatorname{non}\{\ldots\}\}: C^{\{\ldots\}}(x)$,

$\left(^{*}\right)^{\prime}{ }_{\mathrm{w}} ? x \in U^{\{\cdots\}}: C^{\{\ldots\}^{\prime}}(\{\ldots\})$ dlatego, że $(x)$,

$\left({ }^{*}\right)^{\prime}{ }_{\mathrm{U}} ? x \in U^{\{\cdots\}}: C^{\{\ldots\}^{\prime}}(x)$.

W symbolicznych oznaczeniach tych schematów - dla ułatwienie porównywania zapisanych tak samo jak $\mathrm{w}$ monografii — wskaźniki $\mathrm{R}, \mathrm{W}$ i U odsyłają do danej kategorii pytań, natomiast znak prim jest użyty, by odróżnić powyższe schematy dla pytań do wyjaśnienia i do uzupełnienia od ogólniejszych, tj. dających możliwość uwzględnienia dowolnej ich kwantyfikacji. W formułach tych symbol $\{\ldots\}$ oznaczą część osnowy zdania pytajnego, która jest w pytaniu kwestionowana, a symbol $\{\ldots\}$ ' odnosi się do tego, co jest zakładane, tj. do składników osnowy pozostałych, nieobjętych członem pytajnym. Dlatego pierwszy z tych symboli jest użyty na oznaczenie uniwersum $U^{\{\ldots\}}$ odpowiedniego do tego, co kwestionowane, a drugi na oznaczenie warunku $C^{\{\ldots\}^{\prime}}$, który jest w odpowiedzi orzekany o obiektach z danego uniwersum ${ }^{6}$.

\footnotetext{
${ }^{4}$ Pomijam tu kwestię, czy człon „P(x)” da się — zachowując jego oryginalne, tj. Ajdukiewicza rozumienie - rozwinąć i zinterpretować tak, by objąć wszystkie zaproponowane w monografii uszczegółowienia członu , $C^{*}\left(x^{*}\right)$ ”.

${ }^{5}$ Wieloznaczności zdań pytajnych jest w monografii poświęcony rozdział II w JoNKISZ 2020b, 23-41 oraz mój artykuł Jonkisz 2019, 115-134, a strukturze pytań rozdział III w JonKIsz 2020b, 43-73 i artykuł JoNKISZ 2020a, 25-60.

${ }^{6}$ Zapis schematów został tu ujednolicony, tj. w każdym jest symbol $\in$ - zamiast używanych w monografii także, zależnie od ogólności i przedmiotu analiz, zmiennej in lub symbolu $\subset$ -
} 
Dla zilustrowania trafności tych schematów warto je zastosować do konkretnych zdań pytajnych. Spójrzmy najpierw na zdanie pytajne do rozstrzygnięcia oparte na osnowie $p=$ Kolumb odkryt Ameryke, oznaczając składniki tej osnowy skrótami $\mathrm{K}$, o oraz A, a zdanie $p \operatorname{przez}\{\mathrm{K}, \mathrm{o}, \mathrm{A}\}^{7}$.

Zdanie pytajne do rozstrzygnięcia, $\mathrm{tj}$.:

(1) Czy Kolumb odkrył Amerykę?

bywa w konkretnej sytuacji pytajnej rozumiane nie tylko tak, że jego człon pytajny, tj. partykuła „Czy”, odnosi się do całej osnowy p. Oto wszystkie możliwe interpretacje (odczytania) tego zdania, czyli oparte na nim pytania do rozstrzygnięcia ${ }^{8}$.
(i) $=(1)^{\{\mathrm{K}\}}$
Odkryt Amerykę czy \{Kolumb\}?
(ii) $=(1)^{\{0\}}$
Kolumb Amerykę czy \{odkryt\}?
(iii) $=(1)^{\{\mathrm{A}\}}$
Kolumb odkryt czy \{Ameryke\}?
(iv) $=(1)^{\{\mathrm{K}, \mathrm{o}\}}$
Ameryke czy \{Kolumb odkryt\}?
$(\mathrm{v})=(1)^{\{\mathrm{K}, \mathrm{A}\}}$
Odkryt czy \{Kolumb Ameryke\}?
$(\mathrm{vi})=(1)^{\{\mathrm{o}, \mathrm{A}\}}$
Kolumb czy \{odkryt Ameryke\}?
$(\mathrm{vii})=(1)^{\{\mathrm{K}, \mathrm{o}, \mathrm{A}\}}=(1)^{p} \quad C z y\{$ Kolumb odkryt Ameryke $\} ?$

Wynikiem zastosowania schematu $\left({ }^{*}\right)_{\mathrm{R}}$ do pierwszych sześciu spośród tych pytań są, odpowiednio, formuły:

$? x \in\{\{\mathrm{K}\}$, non $\{\mathrm{K}\}\}: C^{\{\mathrm{K}\}}(x)$,

$? x \in\{\{0\}, \operatorname{non}\{0\}\}: C^{\{0\}}(x)$,

$? x \in\{\{\mathrm{A}\}, \operatorname{non}\{\mathrm{A}\}\}: C^{\{\mathrm{A}\}}(x)$,

$\left.? x \in\{\{\mathrm{K}, \mathrm{o}\}, \operatorname{non}\{\mathrm{K}, \mathrm{o}\}\}: C^{\{\mathrm{K}, \mathrm{o}\}}\right\}^{\prime}(x)$,

$? x \in\{\{\mathrm{K}, \mathrm{A}\}, \operatorname{non}\{\mathrm{K}, \mathrm{A}\}\}: C^{\{\mathrm{K}, \mathrm{A}\}}(x)$,

$? x \in\{\{\mathrm{o}, \mathrm{A}\}$, non $\{\mathrm{o}, \mathrm{A}\}\}: C^{\{\mathrm{o}, \mathrm{A}\}}(x)$.

oraz w każdym jest $\mathrm{w}$ ten sam sposób, tj. symbolem $\{\ldots\}$, zaznaczona relatywizacja uniwersum $U$ i warunku $C$ do tego, co jest w pytaniu kwestionowane (w monografii, w schematach struktury pytań do rozstrzygnięcia, relatywizacja ta jest także zaznaczana, co nie jest niezbędne, w indeksie górnym znaku zapytania).

${ }^{7}$ Osnowa jest dobrana tak, by zdanie pytajne były zbliżone do analizowanych w monografii, lecz prostsze pod względem ilości możliwych znaczeń — także dzięki temu, że w osnowie nie ma składnika złożonego (w rodzaju „Amerykę albo Kubę”, „odkrył lub skolonizował” etc.), a także by było niewrażliwe na uwagi co do podstawowego składnika osnowy i sposobu rozumienia tego pojęcia (do sprawy tej powrócę).

${ }^{8}$ Dla ułatwienia zapisu możliwych interpretacji zdania pytajnego (1) jest tu dodany nawias klamrowy, nieużywany w analogicznych zapisach w monografii, który wskazuje na kwestionowaną część osnowy pytania. Jest natomiast, tak jak w monografii, stosowana kursywa przy zapisie pytań, tj. ujednoznacznionych zdań pytajnych, zapisywanych drukiem zwykłym. 
W schematach tych jest widoczna różnica w uniwersach oraz warunkach kolejnych pytań opartych na zdaniu pytajnym (1). Schemat struktury pytania wyznacza także kształt odpowiedzi właściwej, która ma podpadać pod formułę widoczną po dwukropku. Dlatego odpowiednio różnią się także formuły dla odpowiedzi właściwej twierdzącej i odpowiedzi właściwej przeczącej:

$C^{\{\mathrm{K}\}}{ }^{\prime}(\{\mathrm{K}\})$ oraz $C^{\{\mathrm{K}\}}{ }^{\prime}($ non $\{\mathrm{K}\})$,

$C^{\{0\}}(\{0\}) \operatorname{oraz} C^{\{0\}}($ non $\{0\})$,

$C^{\{\mathrm{A}\}^{\prime}}(\{\mathrm{A}\})$ oraz $C^{\{\mathrm{A}\}^{\prime}}(\operatorname{non}\{\mathrm{A}\})$,

$C^{\{\mathrm{K}, \mathrm{o}\}^{\prime}}(\{\mathrm{K}, \mathrm{o}\})$ oraz $C^{\{\mathrm{K}, \mathrm{o}\}^{\prime}}($ non $\{\mathrm{K}, \mathrm{o}\})$,

$C^{\{\mathrm{K}, \mathrm{A}\}^{\prime}}(\{\mathrm{K}, \mathrm{A}\})$ oraz $C^{\{\mathrm{K}, \mathrm{A}\}^{\prime}}($ non $\{\mathrm{K}, \mathrm{A}\})$,

$\left.C^{\{0, A}\right\}^{\prime}(\{\mathrm{o}, \mathrm{A}\})$ oraz $\left.C^{\{\mathrm{o}, \mathrm{A}\}}\right\}^{\prime}($ non $\{\mathrm{o}, \mathrm{A}\})$.

Każda z odpowiedzi twierdzących jest identyczna ze zdaniem $p=\{\mathrm{K}, \mathrm{o}, \mathrm{A}\}$, w kolejnych schematach tych odpowiedzi widać jednak, co w danym pytaniu było kwestionowane, czyli objęte partykułą „Czy”. Różnią się natomiast odpowiedzi przeczące - właśnie wskutek tego, co jest w danym pytaniu wymagane do rozstrzygnięcia i jest $\mathrm{w}$ odpowiedzi rozstrzygane negatywnie. Powyższe formuły odpowiedzi przeczących można w języku naturalnym wypełnić treścią np. tak:

$C^{\{\mathrm{K}\}}($ non $\{\mathrm{K}\}): \quad$ Ktoś odkrył Amerykę, lecz odkrywcą nie był Kolumb.

$C^{\{0\}}($ non $\{0\}): \quad$ Coś (jakaś relacja) wiąże Kolumba z Ameryką, lecz nie jest nią odkrycie.

$\left.C^{\{\mathrm{A}\}}\right\}^{\prime}($ non $\{\mathrm{A}\}): \quad$ Kolumb odkrył jakiś ląd, lecz nie była nim Ameryka.

$C^{\left\{\mathrm{K},{ }^{\circ}\right\}}{ }^{\prime}($ non $\{\mathrm{K}, \mathrm{o}\})$ : Jeśli chodzi o Amerykę, to nie jest tak, że odkrył ją Kolumb.

$C^{\{\mathrm{K}, \mathrm{A}\}}{ }^{\prime}($ non $\{\mathrm{K}, \mathrm{A}\})$ : Są (były) odkrycia, lecz nie należy do nich odkrycie Ameryki przez Kolumba.

$C^{\{\mathrm{o}, \mathrm{A}\}^{\prime}}($ non $\{\mathrm{o}, \mathrm{A}\}):$ Jeśli chodzi o Kolumba, to nie jest tak, że odkrył on Amerykę 9 .

Trzeba dostrzec, że o ile odpowiedź twierdząca na każde z tych pytań jest jednoznaczna, to spośród odpowiedzi przeczących jednoznaczne są tylko pierwsze trzy, tj. odpowiedzi przeczące na pytania, w których jest kwestionowany jeden składnik osnowy. Gdy pytanie dotyczy więcej niż jednego składnika — jak jest w kolejnych trzech pytaniach — lub, warto dodać, gdy

\footnotetext{
${ }^{9}$ Odpowiedzi przeczące są tu wyrażone pełniej niż w przykładach analizowanych w monografii, ponieważ tam sformułowaniom w języku naturalnym towarzyszą ścisłe interpretacje w języku teorii zbiorów, którego tu staram się nie używać.
} 
jest kwestionowany składnik złożony (osnowa do analizy została wybrana tak, by takiego nie było), wtedy odpowiedź przecząca ma tyle uściśleń, ile jest możliwości zanegowania kwestionowanych składników.

Wracając do analizowanego zdania pytajnego (1) można inaczej powiedzieć, że w uniwersach pytań (iv)-(vi), tj. w uniwersach:

(iv) $\{\mathrm{K}, \mathrm{o}\}$, non $\{\mathrm{K}, \mathrm{o}\}\}$,

(v) $\{\mathrm{K}, \mathrm{A}\}, \operatorname{non}\{\mathrm{K}, \mathrm{A}\}$,

(vi) $\{\mathrm{o}, \mathrm{A}\}$, non $\{\mathrm{o}, \mathrm{A}\}$,

za ich zanegowanym składnikiem są „ukryte”, czyli są w uniwersach zawarte nie wprost, następujące możliwości (w ich zapisie non jest skracane przez $n$ ):

$\{n \mathrm{~K}, \mathrm{o}\},\{\mathrm{K}, n \mathrm{o}\},\{n \mathrm{~K}, n \mathrm{o}\}$

$\{n \mathrm{~K}, \mathrm{~A}\},\{\mathrm{K}, n \mathrm{~A}\},\{n \mathrm{~K}, n \mathrm{~A}\}$;

$\{n \mathrm{o}, \mathrm{A}\},\{\mathrm{o}, n \mathrm{~A}\},\{n \mathrm{o}, n \mathrm{~A}\}$.

Wskutek tego również za właściwą odpowiedzią przeczącą jest „ukrytych” tyle samo jednoznacznych, pełnych (i wprost) odpowiedzi negatywnych:

$\{\mathrm{A}\}(\{n \mathrm{~K}, \mathrm{o}\}),\{\mathrm{A}\}(\{\mathrm{K}, n \mathrm{o}\}),\{\mathrm{A}\}(\{n \mathrm{~K}, n \mathrm{o}\}) ;$

$\{\mathrm{o}\}(\{n \mathrm{~K}, \mathrm{~A}\}),\{\mathrm{o}\}(\{\mathrm{K}, n \mathrm{~A}\}),\{\mathrm{o}\}(\{n \mathrm{~K}, n \mathrm{~A}\}) ;$

$\{\mathrm{K}\}(\{n \mathrm{o}, \mathrm{A}\}),\{\mathrm{K}\}(\{\mathrm{o}, n \mathrm{~A}\}),\{\mathrm{K}\}(\{n \mathrm{o}, n \mathrm{~A}\})$.

Nie każda zatem odpowiedź właściwa na pytanie do rozstrzygnięcia jest odpowiedzią pełną. Cechy te współwystępują tylko wtedy, gdy jest kwestionowany jeden (i prosty) składnik osnowy takiego pytania ${ }^{10}$.

W kontekście powyższych ustaleń łatwiej jest odnieść się do ostatniego z pytań opartych na osnowie $p=$ Kolumb odkrył Amerykę:

(vii) $(1)^{\{\mathrm{K}, \mathrm{o}, \mathrm{A}\}}=(1)^{p} \quad C z y\{$ Kolumb odkryt Ameryke $\} ?$,

tj. do pytania:

$C z y\{\mathrm{~K}, \mathrm{o}, \mathrm{A}\} ?=C z y p ?$

\footnotetext{
${ }^{10}$ Uściślone pojęcie odpowiedzi pełnej (także niepełnej i częściowej) jest w monografii stosowane do badania pełności odpowiedzi na pytania dowolnego rodzaju (JonKISz 2020b, 186202), a wnioski dotyczące odpowiedzi pełnych na pytania do rozstrzygnięcia są zebrane w W17 i W18. Tu warto na marginesie dodać, że obecność w osnowie pytania do rozstrzygnięcia składnika złożonego może sprawić, że nie jest jednoznaczna i pełna także odpowiedź twierdząca, jak jest np. dla pytania Czy Kolumb odkryt Amerykę lub Kubę? Odpowiedzi twierdzące pełne to Kolumb odkryt Ameryke, lecz nie odkryt Kuby; Kolumb odkryt Kubę, lecz nie odkryt Ameryki; Kolumb odkryt i Ameryke, i Kubę.
} 
Pytanie to jest skrajne $\mathrm{w}$ tym sensie, że jest $\mathrm{w}$ nim kwestionowana cała osnowa $p=\{\mathrm{K}, \mathrm{o}, \mathrm{A}\}$, co sprawia, że dopełnienie $\{\mathrm{K}, \mathrm{o}, \mathrm{A}\}^{\prime}$ jest zbiorem pustym, a mówiąc inaczej, pusty jest warunek $C^{\{\mathrm{K}, \mathrm{o}, \mathrm{A}\}^{\prime}}$. Dlatego schemat dla tego pytania upraszcza się do:

$?^{p} x \in\{\{\mathrm{K}, \mathrm{o}, \mathrm{A}\}, \operatorname{non}\{\mathrm{K}, \mathrm{o}, \mathrm{A}\}$.

W dwuelementowym uniwersum tego pytania są zatem odpowiedzi na to pytanie właściwe: odpowiedź twierdząca $\{K, \mathrm{o}, \mathrm{A}\}$, wyrażana najczęściej przez „Tak”, oraz przecząca non $\{\mathrm{K}, \mathrm{o}, \mathrm{A}\}$, skracana zwykle do „Nie”. Zbiór odpowiedzi na to pytanie pełnych jest jednak wyznaczony przez zdania wskazane następującymi schematami: $\{\mathrm{K}, \mathrm{o}, \mathrm{A}\} ;\{n \mathrm{~K}, \mathrm{o}, \mathrm{A}\},\{\mathrm{K}, n \mathrm{o}, \mathrm{A}\}$, $\{\mathrm{K}, \mathrm{o}, n \mathrm{~A}\},\{n \mathrm{~K}, n \mathrm{o}, \mathrm{A}\},\{n \mathrm{~K}, \mathrm{o}, n \mathrm{~A}\},\{\mathrm{K}, n \mathrm{o}, n \mathrm{~A}\},\{n \mathrm{~K}, n \mathrm{o}, n \mathrm{~A}\}$. Pierwsza $\mathrm{z}$ nich jest pełną, właściwą odpowiedzią twierdzącą, pozostałe są pełnymi odpowiedziami negatywnymi „ukrytymi” za niepełną odpowiedzią właściwą non $\{\mathrm{K}, \mathrm{o}, \mathrm{A}\}$. Dla pytań $C z y$ p? jest więc tak, że możliwości „ukryte” za zanegowanym elementem uniwersum, zawarte $\mathrm{w}$ uniwersum nie wprost, są zdaniami, tj. pełnymi odpowiedziami negatywnymi. Spośród nich nowa w porównaniu z innymi niż $C z y$ p? pytaniami do rozstrzygnięcia opartymi na $p=$ Kolumb odkryt Ameryke — jest odpowiedź $\{n \mathrm{~K}, n \mathrm{o}, n \mathrm{~A}\}$. Dlatego jest w przypadku takich pytań jeszcze wyraźniej widoczne, że właściwa odpowiedź przecząca jest wieloznaczna i niepełna. Stwierdzenie to nabiera wagi, gdy sprowadzi się formuły dla pytań i dopowiedzi na pytania $C z y p$ ? do postaci, w której są zwykle analizowane.

Schemat

$? x \in\{\{\mathrm{K}, \mathrm{o}, \mathrm{A}\}, \operatorname{non}\{\mathrm{K}, \mathrm{o}, \mathrm{A}\}\}$

przyjmuje kształt

$? x \in\{p, \operatorname{non}\{p\}\}$

a ponieważ zdanie non $p$ jest równoważne $\mathrm{z}$ negacją $\sim p$, więc ostatecznie formuła ta upraszcza się do

$? x \in\{p, \sim p\}^{11}$.

\footnotetext{
${ }^{11}$ Wzmiankowane tu pojęcia i twierdzenia dotyczące reprezentowania $\mathrm{w}$ analizie pytań ich osnowy oraz rozumienia i własności negacji non $\{\ldots\}$ są w monografii uściślone i udowodnione (zob. D2, D3, W2a, W2.b, W2b', L1, L2, W3, W4, W5, Jonkisz 2020b, 44-58) - do kwestii tych odniosę się szerzej w uwagach metodologicznych.
} 
Znaczenia pełnych odpowiedzi przeczących łatwiej jest wskazać w sztucznym, symbolicznym języku analiz niż wyrazić w języku naturalnym. Oto przykładowe (możliwie zwięzłe) przekłady powyższych formuł:

$\{n \mathrm{~K}, \mathrm{o}, \mathrm{A}\}: \quad$ Ameryka została odkryta, lecz nie przez Kolumba;

$\{\mathrm{K}, n \mathrm{o}, \mathrm{A}\}: \quad$ Kolumba wiąże coś z Ameryką, lecz nie jest to jej odkrycie;

$\{\mathrm{K}, \mathrm{o}, n \mathrm{~A}\}: \quad$ Kolumb odkrył jakiś ląd, lecz nie była nim Ameryka;

$\{n \mathrm{~K}, n \mathrm{o}, \mathrm{A}\}$ : Jeśli chodzi o Amerykę, to ani Kolumb, ani odkrycie;

$\{n \mathrm{~K}, \mathrm{o}, n \mathrm{~A}\}:$ Jeśli chodzi o odkrycia, to ani Kolumb, ani Ameryka;

$\{\mathrm{K}, n \mathrm{o}, n \mathrm{~A}\}$ : Jeśli chodzi o Kolumba, to ani odkrycie, ani Ameryka;

$\{n \mathrm{~K}, n \mathrm{o}, n \mathrm{~A}\}$ : Ani Kolumb, ani odkrycie, ani Ameryka.

Są wprawdzie w konkretnych sytuacjach możliwe i tak skrótowe, domyślne wypowiedzi, zwykle jednak udzielenie odpowiedzi pełnej wymaga nie tylko wypowiedzi niemieszczącej się w schemacie odpowiedzi właściwej, lecz uzupełnienia jej o twierdzenia — wypowiedziane bądź znane i uznawane w sytuacji pytajnej — z których koniunkcji wynika odpowiedź pełna wprost, podpadająca pod dany schemat, a z niej dopiero właściwa odpowiedź przecząca. Gdy na przykład na pytanie:

$$
\text { (1) }{ }^{\{0, A\} \quad K o l u m b} \text { czy \{odkryt Amerykę? }
$$

odpowiadający stwierdza (nieważne tu, czy prawdziwie), że Kolumb nie dokonał odkrycia, bo jedynie opłynął dostrzeżony ląd, a przy tym opłynął nie Amerykę, lecz Kubę - wtedy z twierdzeń tych wynika, że uznaje odpowiedź negatywną o formie:

$\{\mathrm{K}\}(\{n \mathrm{o}, n \mathrm{~A}\})=\{\mathrm{K}, n \mathrm{o}, n \mathrm{~A}\}$.

Aby lepiej zilustrować to, że wyróżniane w ogólnych analizach formuły dla pytań i odpowiedzi mają, a na pewno mogą mieć odpowiedniki w sytuacjach pytajnych, rozważmy zdanie pytajne, którego interpretacje są mniej niż zdania (1) skrępowane uznawanymi powszechnie za prawdziwe twierdzeniami o przedmiocie pytania.

(2) Czy Kazimierz złowił troć?

Przyjmując, że osnowa $p$ tego pytania jest reprezentowana przez $\{\mathrm{K}, \mathrm{z}, \mathrm{T}\}$, można zapisać i oznaczyć oparte na niej pytania:
(i) $=(2)^{\{\mathrm{K}\}}$
Złowił troć czy \{Kazimierz\}?
(ii) $=(2)^{\{z\}}$
Kazimierz troć czy \{zlowit\}? 


$\begin{array}{ll}(\mathrm{iii})=(2)^{\{\mathrm{T}\}} & \text { Kazimierz złowit czy }\{\text { troć }\} ? \\ \text { (iv) }=(2)^{\{\mathrm{K}, \mathrm{z}\}} & \text { Troć czy }\{\text { Kazimierz ztowit\}? } \\ (\mathrm{v})=(2)^{\{\mathrm{K}, \mathrm{T}\}} & \text { Złowit czy }\{\text { Kazimierz troć }\} ? \\ (\mathrm{vi})=(2)^{\{\mathrm{z}, \mathrm{T}\}} & \text { Kazimierz czy }\{\text { złowit troć\}? } \\ (\mathrm{vii})=(2)^{\{\mathrm{K}, \mathrm{z}, \mathrm{T}\}}=(1)^{p} & \text { Czy }\{\text { Kazimierz złowit troć }\} ?\end{array}$

Oto uniwersa tych pytań - dwuelementowe oraz rozwinięte tak samo, jak dla pytań opartych na zdaniu pytajnym (1); rozwinięcia są zapisane ze skrótem non \{\}$=n$ oraz średnikiem oddzielającym element uniwersum związany z odpowiedzią twierdzącą od elementów „negatywnych”, tj. związanych z odpowiedzią przeczącą:

$$
\begin{aligned}
& U^{\{\mathrm{K}\}}=\{\{\mathrm{K}\}, \text { non }\{\mathrm{K}\}\} ; \quad\{\{\mathrm{K}\} ;\{n \mathrm{~K}\}\} \\
& U^{\{\mathrm{z}\}\}}=\{\quad\{\{\mathrm{z}\}, \operatorname{non}\{\mathrm{z}\}\} ;\{\{\mathrm{z}\} ;\{n \mathrm{z}\}\} \\
& U^{\{\mathrm{T}\}}=\{\{\mathrm{T}\}, \operatorname{non}\{\mathrm{T}\}\} ; \quad\{\{\mathrm{T}\} ;\{n \mathrm{~T}\}\} \\
& U^{\{\mathrm{K}, \mathrm{z}\}}=\{\{\mathrm{K}, \mathrm{z}\}, \text { non }\{\mathrm{K}, \mathrm{z}\}\} ; \quad\{\{\mathrm{K}, \mathrm{z}\} ;\{n \mathrm{~K}, \mathrm{z}\},\{\mathrm{K}, n \mathrm{z}\},\{n \mathrm{~K}, n \mathrm{z}\}\} \\
& U^{\{\mathrm{K}, \mathrm{T}\}}=\{\{\mathrm{K}, \mathrm{T}\}, n \text { on }\{\mathrm{K}, \mathrm{T}\}\} ; \quad\{\{\mathrm{K}, \mathrm{T}\} ;\{n \mathrm{~K}, \mathrm{~T}\},\{\mathrm{K}, n \mathrm{~T}\},\{n \mathrm{~K}, n \mathrm{~T}\}\} \\
& U^{\{\mathrm{z}, \mathrm{T}\}}=\{\{\mathrm{z}, \mathrm{T}\}, n o n\{\mathrm{z}, \mathrm{T}\}\} ; \quad\{\{\mathrm{z}, \mathrm{T}\} ;\{n \mathrm{z}, \mathrm{T}\},\{\mathrm{z}, n \mathrm{~T}\},\{n \mathrm{z}, n \mathrm{~T}\}\} \\
& U^{\{\mathrm{K}, \mathrm{z}, \mathrm{T}\}}=U^{p}=\{\{\mathrm{K}, \mathrm{z}, \mathrm{T}\}, \text { non }\{\mathrm{K}, \mathrm{z}, \mathrm{T}\}\} ;\{\{\mathrm{K}, \mathrm{z}, \mathrm{T}\} ;\{n \mathrm{~K}, \mathrm{z}, \mathrm{T}\},\{\mathrm{K}, n \mathrm{z}, \mathrm{T}\},\{\mathrm{K}, \mathrm{z}, \\
& n \mathrm{~T}\},\{n \mathrm{~K}, n \mathrm{z}, \mathrm{T}\},\{n \mathrm{~K}, \mathrm{z}, n \mathrm{~T}\},\{\mathrm{K}, n \mathrm{z}, \\
& n \mathrm{~T}\},\{n \mathrm{~K}, n \mathrm{Z}, n \mathrm{~T}\}\} \text {. }
\end{aligned}
$$

Odpowiedzią twierdzącą na każde z pytań (i)-(vii) jest zdanie $\{\mathrm{K}, \mathrm{z}, \mathrm{T}\}$. Co się natomiast tyczy odpowiedzi przeczącej, to by uprościć tę ilustrację, warto rozpocząć od pytania (vii), którego analiza ujawni wszystkie wchodzące $\mathrm{w}$ grę możliwości związane $\mathrm{z}$ odpowiedziami przeczącymi na pytania oparte na osnowie $p$. W uniwersum tego pytania są zdania - potencjalne odpowiedzi właściwe na to pytanie: odpowiedź twierdząca $\{\mathrm{K}, \mathrm{z}, \mathrm{T}\}$, oraz przecząca non $\{\mathrm{K}, \mathrm{z}, \mathrm{T}\}$. Zbiór odpowiedzi na to pytanie pełnych jest jednak wyznaczony przez 8 zdań, tj. odpowiedź twierdzącą $\{K, z, T\}$ oraz zdania o strukturze:
(a) $\{n \mathrm{~K}, \mathrm{z}, \mathrm{T}\}$,
(b) $\{\mathrm{K}, n \mathrm{z}, \mathrm{T}\}$,
(c) $\{\mathrm{K}, \mathrm{z}, n \mathrm{~T}\}$,
(d) $\{n \mathrm{~K}, n \mathrm{z}, \mathrm{T}\}$,
(e) $\{n \mathrm{~K}, \mathrm{z}, n \mathrm{~T}\}$,
(f) $\{\mathrm{K}, n \mathrm{z}, n \mathrm{~T}\}$,
(g) $\{n \mathrm{~K}, n \mathrm{z}, n \mathrm{~T}\}$. 
W rzeczywistych sytuacjach odpowiadania zdanie $\{\mathrm{K}, \mathrm{z}, \mathrm{T}\}$ jest wyrażane najczęściej przez „Tak”, a odpowiedzi negatywne (a)-(g) są reprezentowane skrótem „Nie”, wyrażającym odpowiedź właściwą przeczącą. Odpowiedzi wskazane formułami (a)-(g) także można próbować wyrażać zwięźle w języku naturalnym, zwykle jednak wynikają one z bardziej złożonych i nie tylko przeczących wypowiedzi, które w konkretnej sytuacji są dorzecznymi i pełnymi odpowiedziami nie wprost (przykładowe są zapisane w nawiasie kwadratowym).

$\{n \mathrm{~K}, \mathrm{z}, \mathrm{T}\}:$ Ktoś złowił troć, lecz nie Kazimierz. [To Marek złowił troć],

$\{\mathrm{K}, n z, \mathrm{~T}\}$ : Relacja Kazimierz-troć nie jest złowieniem [Kazimierz nie złowił, lecz widział troć],

$\{\mathrm{K}, \mathrm{z}, n \mathrm{~T}\}$ : Kazimierz coś złowił, lecz nie troć [Kazimierz złowił szczupaka],

$\{n \mathrm{~K}, n \mathrm{z}, \mathrm{T}\}$ : Jeśli chodzi o troć, to ani Kazimierz, ani złowił [Nikt nie złowił, Zygmunt widział troć],

$\{n \mathrm{~K}, \mathrm{z}, n \mathrm{~T}\}$ : Jeśli chodzi o złowienie, to ani Kazimierz, ani troć [Złowił Janek szczupaka],

$\{\mathrm{K}, n \mathrm{z}, n \mathrm{~T}\}$ : Jeśli chodzi o Kazimierza, to ani złowił, ani troć [Kazimierz holowat bolenia],

$\{n \mathrm{~K}, n \mathrm{z}, n \mathrm{~T}\}$ : Ani Kazimierz, ani złowił, ani troć [Irena kupiła łososia].

Spośród odpowiedzi pełnych na pytanie $C z y\{\mathrm{~K}, \mathrm{z}, \mathrm{T}\}$ ? niektóre tylko są pełnymi odpowiedziami wprost na pytania (i)-(vi). Dla wszystkich pytań wspólna jest pełna wprost (i właściwa) odpowiedź twierdząca, natomiast jeśli chodzi o odpowiedzi negatywne, to pytania (i)-(iii) mają jedną tylko taką odpowiedź pełną wprost, a jest nią ich przecząca odpowiedź właściwa, tj., odpowiednio, odpowiedź (a), (b), (c). Z kolei odpowiedzi przeczące pełne wprost na kolejne pytania, to:

na pytanie (iv) - odpowiedzi (a), (b), (d);

na pytanie (v) - (a), (c), (e);

na pytanie (vi) - zdania (b). (c), (f) ${ }^{12}$.

\footnotetext{
${ }^{12}$ Pojęcia tu jedynie wzmiankowane - tj. pojęcie zbioru możliwości wyznaczających zbiór odpowiedzi pełnych oraz pojęcie zbioru odpowiedzi pełnych - a także pojęcia odnoszące się do rodzajów odpowiedzi są w monografii uściślone, omawiane i zilustrowane wieloma przykładami. Uściślenia potrzebne do analizowania pytań do rozstrzygnięcia i odpowiedzi na takie pytania są zdefiniowane w (D2), (D3) i (D8), a koncepcja odpowiedzi — w niej podziały odpowiedzi na dorzeczne (zawężające, korygujące); pełne, niepełne, częściowe; wprost, niewprost; adekwatne, nieadekwatne itd. — jest omówiona w rozdziale VI (Jonkisz 2020b, 175-246).
} 
Użyteczność uwzględnionego w schemacie (*) pojęcia uniwersum, uszczegółowionego odpowiednio do konkretnego pytania, jest widoczna także dla zdań pytajnych problemowych. Na przykład, dla zdania pytajnego:

(3) Dlaczego Jan studiuje filozofię?

da się wskazać - w wyniku analizy analogicznej jak dla zdań (1) i (2) wszystkie jego możliwe interpretacje, tj. pytania oparte na osnowie $p=J a n$ studiuje filozofie (reprezentowanej układem $\{\mathrm{J}, \mathrm{s}, \mathrm{F}\})^{13}$ :
(i) $=(3)^{\{\mathrm{J}\}}$
Studiuje filozofię dlaczego \{Jan\}?
(ii) $=(3)^{\{s\}}$
Jan filozofię dlaczego \{studiuje\}?
(iii) $=(3)^{\{\mathrm{F}\}}$
Jan studiuje dlaczego \{filozofie\}?
(iv) $=(3)^{\{\mathrm{J}, \mathrm{s}\}}$
Filozofie dlaczego \{Jan studiuje\}?
$(\mathrm{v})=(3)^{\{\mathrm{J}, \mathrm{F}\}}$
Studiuje dlaczego \{Jan filozofie\}?
$(\mathrm{vi})=(3)^{\{\mathrm{s}, \mathrm{F}\}}$
Jan dlaczego \{studiuje filozofie\}?
$\left(\right.$ vii) $=(3)^{\{\mathrm{J}, \mathrm{s}, \mathrm{F}\}}=(1)^{p}$
Dlaczego \{Jan studiuje filozofie\}?

Strukturę tych pytań, zrekonstruowaną według schematu:

$(*)^{\prime}{ }_{\mathrm{w}} ? x \in U^{\{\ldots\}}: C^{\{\ldots\}^{\prime}}(\{\ldots\})$ dlatego, $\dot{z} e(x)$,

ukazują formuły:
(i) $\quad ? x \in U^{\{\mathrm{J}\}}: C^{\{\mathrm{J}\}}(\{\mathrm{J}\})$
dlatego, $\dot{z} e(x)$,
(ii) $\quad ? x \in U^{\{\mathrm{s}\}}: C^{\{\mathrm{s}\}^{\prime}}(\{\mathrm{s}\})$
dlatego, $\dot{z} e(x)$,
(iii) $? x \in U^{\{\mathrm{F}\}}: C^{\{\mathrm{F}\}^{\prime}}(\{\mathrm{F}\})$
dlatego, $\dot{z} e(x)$,
(iv) $\quad ? x \in U^{\{\mathrm{J}, \mathrm{s}\}}: C^{\{\mathrm{J}, \mathrm{s}\}^{\prime}}(\{\mathrm{J}, \mathrm{s}\})$
dlatego, $\dot{z} e(x)$.
(v) $\quad ? x \in U^{\{\mathrm{J}, \mathrm{F}\}}: C^{\{\mathrm{J}, \mathrm{F}\}^{\prime}}(\{\mathrm{J}, \mathrm{F}\}) \quad$ dlatego, $\dot{z} e(x)$,
(vi) $? x \in U^{\{\mathrm{s}, \mathrm{F}\}}: C^{\{\mathrm{s}, \mathrm{F}\}}(\{\mathrm{s}, \mathrm{F}\}) \quad$ dlatego, $\dot{z} e(x)$,
(vii) $? x \in U^{\{\mathrm{J}, \mathrm{s}, \mathrm{F}\}}$ :
$p$ dlatego, $\dot{z} e(x)^{14}$.

W części tych formuł dotyczących przedmiotu pytania (przed dwukropkiem) jest wskazane uniwersum, z którego trzeba czerpać wyjaśnienia podawane w odpowiedzi. W uniwersach dla pytań (i)-(vii) są zdania wyjaśniające, dlaczego:

${ }^{13}$ Wieloznaczność kwantyfikacji, która może dotykać także pytań problemowych, omówię odrębnie.

${ }^{14} \mathrm{~W}$ monografii są ponadto omawiane i stosowane schematy dla pytań problemowych rozumianych przyczynowo albo celowościowo oraz ich odmian sformułowanych w stylizacji zdaniowej albo nazwowej, tj.:

$\left.{ }^{*}\right)^{\prime}{ }_{\mathrm{wp}} ? x$ in $U^{\{\ldots\}}$ : Powodem tego, że $C^{\{\ldots\}^{\prime}}(\{\ldots\})$ byto to, że/było $(x)$

$\left({ }^{*}{ }^{\prime}{ }_{\mathrm{Wc}}\right.$ ? $x$ in $U^{\{\ldots\}}$ : Celem tego, że $C^{\{\ldots\}}(\{\ldots\})$ byto to, że/byto $(x)$. 
$U^{\{\mathrm{J}\}} \quad-$ Jan [studiuje filozofię],

$U^{\{s\}} \quad-$ studiuje [Jan filozofię],

$U^{\{\mathrm{F}\}} \quad-$ filozofię [Jan studiuje],

$U^{\{\mathrm{J}, \mathrm{s}} \quad-$ Jan studiuje [filozofię],

$U^{\{\mathrm{J}, \mathrm{F}\}}$ - Jan filozofię [studiuje],

$U^{\{\mathrm{s}, \mathrm{F}\}}-$ studiuje filozofię [Jan],

$U^{\{\mathrm{J}, \mathrm{s}, \mathrm{F}\}}-$ Jan studiuje filozofię.

Odpowiednia do uniwersum pytania jest także struktura odpowiedzi właściwej. Wprawdzie w każdej $\mathrm{z}$ tych formuł człon widoczny po dwukropku, a przed „dlatego” jest identyczny ze zdaniem Jan studiuje filozofię, jest jednak w tym członie wskazane, czego pytanie dotyczy, czyli co w odpowiedzi trzeba wyjaśnić. Dlatego w odpowiedziach na te pytania mogą się pojawić na przykład takie wyjaśnienia:

(a): Miał studiować Andrzej, lecz wybrał kierunek, po którym łatwiej znaleźć pracę.

(b): By dalej otrzymywać stypendium.

(c): Niestety, nie dostał się na psychologię.

(d): Ponieważ Andrzej już pracuje, a Jan woli studiować niż pracować.

(e): Jan chciał studiować razem z Andrzejem, a Andrzej studiuje filozofię.

(f): By nie iść do wojska, a filozofię, bo przyjmują wszystkich.

(g): Andrzej jest jeszcze w liceum, a Jan zawsze chciał studiować coś nietypowego.

Jest oczywiste, że w odpowiedziach na pytania „obszerniejsze” są zawarte oparte na danej osnowie pełne odpowiedzi na pytania „węższe”; a gdy przedmioty pytań się krzyżują, wtedy z każdej odpowiedzi na jedno z takich pytań wynika odpowiedź częściowa na drugie pytanie z takiej pary. Mianowicie:

- odpowiedź na pytanie (vii) jest też odpowiedzią pełną (choć niewłaściwą i niewprost), na każde z pytań (i)-(vi);

- odpowiedź na (vi) zawiera (implikuje) odpowiedzi pełne na pytania (ii) oraz (iii), a na pytania (iv), (v) i (vii) jest odpowiedzią (niewłaściwą i niewprost) częściową;

- odpowiadając na (v), odpowiada się także w sposób pełny niewprost na (i) i (iii), a częściowo na (iv), (vi) i (vii);

- (iv) jest odpowiedzią pełna (niewłaściwą i niewprost) na (i) i (ii), a częściową na (v), (vi) i (vii); 
- (iii) jest odpowiedzią częściową na pytania (v), (vi) i (vii);

- (ii) jest odpowiedzią częściową na (iv), (vi) i (vii);

- (i) jest częściową odpowiedzią na (iv) (v) i (vii).

Pojęcie przedmiotu pytania, tj. uniwersum i odpowiedniej dlań niewiadomej pytania, jest także niezbędne w trafnym ujęciu struktury pytań do uzupełnienia. Aby zilustrować skuteczności schematu

$\left({ }^{*}\right)^{\prime}{ }_{\mathrm{U}} ? x \in U^{\{\cdots\}}: C^{\{\cdots\}}(x)$,

rozważmy zdanie $p=$ Piotr zdat egzamin, użyte jako osnowa różnych zdań pytajnych do uzupełnienia (nadal pomijana będzie kwantyfikacji pytania, mimo że jest ona dla pytań do uzupełnienia źródłem wieloznaczności o wiele częstszym niż dla pytań problemowych).

Oto przykłady zdań pytajnych uzyskanych w wyniku zastąpienia składników zdania $p$ odpowiednim zaimkiem lub, ogólniej — członem pytajnym:

(4a) Kto zdał egzamin?

(4b) Co wiąże Piotra $z$ egzaminem?

(4c) Co Piotr zdał?

(4d) Kto i co zdał? ${ }^{15}$

Formuły ujmujące strukturę takich pytań są uszczegółowieniem schematu $\left({ }^{*}\right)_{\mathrm{U}}$, w którym jest wskazany ten składnik zdania Piotr zdat egzamin, którego pytanie dotyczy (składniki te są oznaczone kolejno cyframi 1-3):

(4a) ? $x \in U^{\{1\}}: C^{\{1\}^{\prime}}(x)$,

(4b) $? x \in U^{\{2\}}: C^{\{2\}^{\prime}}(x)$,

(4c) ? $x \in U^{\{3\}}: C^{\{3\}^{\prime}}(x)$,

(4d) ? $<x, y>\in U^{\{1,3\}}: C^{\{1,3\}^{\prime}}(x)$.

W uniwersum $U^{\{1\}}$ są nazwy osób; w $U^{\{2\}}$ są wyrażenia takie, jak ,zdał”, „ma zdawać”, „oblał”, „przełożył”; podstawiane za $x$ w $U^{\{3\}}$ są nazwy „egzamin”, „kolokwium”, „maturę”, „test” etc.; natomiast uniwersum $U^{\{1,3\}}$ jest iloczynem $U^{\{1\}} \times U^{\{3\}}$ i są $\mathrm{w}$ nim pary takie np., jak $\langle$ Piotr, egzamin $\rangle$, $\langle$ Andrzej, matura $\rangle,\langle$ Jan, egzamin $\rangle$, $\langle$ Paweł, kolokwium $\rangle$. Schematy te wyznaczają jednocześnie formę odpowiedzi właściwej: elementy z $U^{\{1\}}$ są podstawiane za zmienną $x$ w funkcji zdaniowej Egzamin zdat $(x)$; wyrażenia $\mathrm{z} U^{\{2\}}$ są użyte $\mathrm{w}$ schemacie odpowiedzi właściwej Piotra $z$ egzaminem wiąże to, że $(x) ; \mathrm{z}^{\{3\}}$ są czerpane wartości dla zmiennej w formule Piotr

\footnotetext{
pytań.

${ }^{15}$ Mowa o zdaniach pytajnych, bo wchodzi w grę możliwa kwantyfikacja opartych na nich
} 
zdat $(x)$, a ze złożonego uniwersum $U^{\{1,3\}}$ są brane uporządkowane pary widoczne w odpowiedzi o budowie $Z d a t\langle x, y\rangle$.

Spójrzmy teraz na takie zdania pytajne do uzupełnienia, w których człon pytajny poprzedza osnowę będącą pełnym zdaniem oznajmiającym. Oto przykłady takich pytań o trzonie $p=$ Piotr zdat egzamin:

(5a) Który Piotr zdał egzamin?

(5b) Kiedy Piotr zdał egzamin?

(5c) Z czego Piotr zdał egzamin?

(5d) Z czego i na ile Piotr zdał egzamin?

(5e) Jak to było/się stało, że Piotr zdał egzamin?

Strukturę tych pytań oddają formuły, które są uszczegółowieniami schematu:

$\left({ }^{*}\right)^{\prime}{ }_{\mathrm{U} i} ? x \in U_{i}: p(x)$

albo podpadają pod

$\left({ }^{*}\right)^{\prime} \mathrm{U} p ? x \in U_{p}: p(x)$.

Uszczegółowienie polega na wskazaniu tego składnika osnowy, którego dotyczy pytanie (człon pytajny), jest przy tym możliwe, że dotyczy więcej niż jednego składnika, a także całej osnowy. Oto odpowiednie formuły (składniki osnowy są oznaczone cyframi tak samo, jak dla zdań pytajnych 4):

(5a) ? $x \in U_{1}: p(x)$,

(5b) $? x \in U_{2}: p(x)$,

(5c) ? $x \in U_{3}: p(x)$,

(5d) ? $<x, y>\in U_{3,2}: p(<x, y>)$,

(5e) ? $x \in U_{p}$ : to, że $p$ było/stało się tak, że $(x)$.

W uniwersum $U_{1}$ są nazwy wskazujące na konkretnego spośród możliwych Piotrów (np. nazwiska albo opisy wskazujące na osobę); w $U_{2}$ są nazwy godzin lub dni/tygodni/miesięcy/lat — zależnie od określonej przez sytuację pytajną, oczekiwanej dokładności odpowiedzi; z $U_{3}$ są w odpowiedzi czerpane nazwy przedmiotów objętych egzaminem; a co do uniwersum $U_{3,2}$, to jeśli w uniwersum $U$ są nazwy ocen, to $U_{3,2}$ jest identyczne z iloczynem $U_{3} \times U$ i zawiera takie pary uporządkowane, jak 〈matematyka, dobry $\rangle,\langle\operatorname{logika}$, dostateczny plus $\rangle$ itd., których elementy są odpowiednio podstawiane w schemacie odpowiedzi Piotr zdal egzamin z $x$ na (ocene) $y$. Natomiast uniwersum $U_{p}$ ostatniego pytania zawiera różne opisy uwzględniające np. przyczyny, motywy, okoliczności, przebieg — zdające 
sprawę, jak doszło do tego, co się złożyło na to, co sprawiło, że: Piotr zdał $\operatorname{egzamin}^{16}$.

\section{KWANTYFIKACJA PYTANIA}

Gdy mowa tu o kwantyfikacji, chodzi o kwantyfikację tzw. pragmatyczną, odróżnioną od językowej. Wieloznaczność kwantyfikacji językowa ma źródło w użytych w zdaniu pytajnym niejednoznacznych wyrażeniach wskazujących na ilość, takich np. jak „wielu”, „niewielu”, „liczni” „nieliczni”, „sporo”, „mało” etc. Natomiast wieloznaczne pod względem kwantyfikacji pragmatycznej mogą być zdania pytajne językowo jednoznaczne. Chodzi bowiem o niejednoznaczność co do tego, ile możliwości z zakresu niewiadomej trzeba wskazać w odpowiedzi. Wieloznaczność tego rodzaju dotyka zwłaszcza zdań pytajnych do uzupełnienia, rzadziej - do wyjaśniania.

Dla zilustrowania, jak schematy oparte na $\left({ }^{*}\right)_{\mathrm{U}} \mathrm{i}\left({ }^{*}\right)_{\mathrm{W}}$ radzą sobie z kwantyfikacją pragmatyczną, rozważmy zdania pytajne (pierwsze jest identyczne z 4a):

(6a) Kto studiuje filozofię?

(6b) Kto co studiuje?

(6c) Kto komu co dał?

Schematy tych zdań pytajnych nieuwzględniające kwantyfikacji to:

(6a) ? $x \in U^{\{1\}}: C^{\{1\}^{\prime}}(x)$,

(6b) ? $<x, y>\in U^{\{1,3\}}: C^{\{1,3\}^{\prime}}(\langle x, y\rangle)$

- w formułach tych wskaźniki odsyłają do domyślnego zdania Ktoś studiuje coś, którego składniki są oznaczone kolejnymi cyframi — oraz

(6c) ? $\langle x, y, z\rangle \in U^{\{1,3,4\}}: C^{\{1,3,4\}^{\prime}}(\langle x, y, z\rangle)$,

zakładającego z kolei zdanie o budowie Ktoś dat komuś coś (np. Piotr dał Zosi kwiaty), którego kolejne słowa są oznaczone przez 1, 2, 3 i 4. Uniwersa tych schematów są odpowiednio utworzone ze zbiorów, w których są nazwy osób, kierunków studiów oraz obiektów, o których w sytuacji pytajnej wiadomo, że mogą być dane - nazwy te są podstawiane w schematach odpowiedzi, tj. w:

Studiuje filozofię (x); Studiuje ( $\langle x, y\rangle) ;$ Dat $(\langle x, y, z\rangle)$.

\footnotetext{
${ }^{16}$ Takie zdania pytajne i oparte na nich pytania bywają umieszczane w odrębnej kategorii pytań zwanych narracyjnymi lub pytaniami domagających się narracji, opowiadania (kategorię tę wydzielał np. ks. prof. Stanisław Kamiński w swoich wykładach z ogólnej metodologii nauk).
} 
Zdania pytajne wieloznaczne pragmatycznie wymagają pod tym względem ujednoznacznienia: czy w odpowiedzi ma być wskazana dokładnie jedną możliwość z uniwersum $(n=1)$, dokładnie $k$ takich możliwości $(n=k)$, ogół takich możliwości albo też trzeba, odpowiadając, spełnić jakieś inne wymaganie co do ilości, np. $n \geq 3,2 \leq n<5$.

Oto przykłady formuł wskazujących na kwantyfikacje zdań pytajnych (6a)-(6c):

(6a) Kto studiuje filozofię?

$$
\begin{array}{ll}
n=3 & ?\{x, y, z\} \subset U^{\{1\}}: C^{\{1\}^{\prime}}(x) \wedge C^{\{1\}^{\prime}}(y) \wedge C^{\{1\}^{\prime}}(z), \\
\text { „wszystkie” } & ? A \subset U^{\{1\}}: A=\left\{x \in U^{\{1\}}: C^{\{1\}^{\prime}}(x)\right\}, \\
n \geq 4 & ? A \subset U^{\{1\}}: A \subset\left\{x \in U^{\{1\}}: C^{\{1\}^{\prime}}(x)\right\} \wedge\|A\| \geq 4 .
\end{array}
$$

(6b) Kto co studiuje?

$$
\begin{array}{ll}
n=2 & ?\left\{<x_{1}, y_{1}>,<x_{2}, y_{2}>\right\} \subset U^{\{1,3\}}: C^{\{1,3\}^{\prime}\left(<x_{1}, y_{1}>\right) \wedge} \\
& C^{\{1,3\}^{\prime}}\left(<x_{2}, y_{2}>\right), \\
\text { „wszystkie” } & ? A \subset U^{\{1,3\}}: A=\left\{<x, y>\in U^{\{1,3\}}: C^{\{1,3\}^{\prime}}(<x, y>)\right\} .
\end{array}
$$

(6c) Kto komu co dał?

$$
\begin{array}{ll}
n=1 & ?\{<x, y, z>\} \subset U^{\{1,3,4\}}: C^{\{1,3,4\}^{\prime}}(<x, y, z>), \\
2 \leq n<6 & ? A \subset U^{\{1,3,4\}}: A \subset\left\{<x, y, z>\in U^{\{1,3,4\}}: C^{\{1,3,4\}^{\prime}}(<x, y,\right. \\
& z>)\} \wedge 2 \leq\|A\|<6 .
\end{array}
$$

W schematach uwzględniających kwantyfikację pojawiają się zbiory możliwości z uniwersum, a wymaganą liczność tych zbiorów można wskazać albo bezpośrednio, jak w pierwszym przykładzie dla każdego z tych pytań, albo stawiając w schemacie dodatkowy warunek określające liczność zbioru $A$. Jedynie dla kwantyfikacji ,wszystkie” wystarczy mówić po prostu o zbiorze (ogóle) $A$ takich możliwości. Gdy jest zadawane pytanie skwantyfikowane, zwykle nie mówi się o zbiorze, na wymaganą ilość wskazuje najczęściej dodatkowe polecenie (np. wymień co najmniej dwie ...; ... proszę wyliczyć wszystkie). Wprowadzenie do schematów zmiennej dla zbiorów i wskazanie na liczność jest jednak, najprostszym jak sądzę, sposobem ujmowania dowolnej pragmatycznej kwantyfikacji ${ }^{17}$.

\footnotetext{
${ }^{17}$ Tak samo da się zaznaczać wymaganą kwantyfikację w innych schematach pytań omówionych $\mathrm{w}$ monografii, $\mathrm{z}$ których tylko wybrane zostały przypomniane $\mathrm{w}$ niniejszym artykule. W monografii są np. omawiane także schematy, w których zamiast $A \subset U$ jest napis $A \in \operatorname{Pot}(U)$ — schematy tu pominięte, także dlatego, że oba ujęcia są równoważne.
} 
Tak samo jak w przypadku pytań do uzupełnienia, da się oddać kwantyfikację pytań do wyjaśnienia. Wprawdzie zdania pytajne do wyjaśnienia rzadziej niż do uzupełnienia są skwantyfikowane i wymagają pod tym względem ujednoznacznienia, jednak i dla wyjaśnień wymagania takie bywają formułowane, np. poleceniem, wplecionym w zdanie pytajne bądź sformułowanym odrębnie, bo podać co najmniej dwa wyjaśnienia:

\section{(7) Dlaczego Polacy emigrują?}

W schemacie opartego na (7) pytania tak skwantyfikowanego, tj. w:

? $A \subset U^{p}: A \subset\left\{x \in U^{p}: p\right.$ dlatego, $\left.\dot{z} e(x)\right\} \wedge\|A\| \geq 2$,

widać, że „Dlaczego” dotyczy całej osnowy $p=$ Polacy emigruja, a warunek końcowy wskazuje na kwantyfikację.

Dlatego, pomijając obszerniejsze analizowanie zdań pytajnych do wyjaśnienia, poprzestanę na uzupełnieniu stosowanych wyżej formuł $(*)^{\prime}{ }_{\mathrm{W}},(*)_{\mathrm{U}}$, $(*)^{\prime}{ }_{\mathrm{U} i} \mathrm{i}\left({ }^{*}\right)^{\prime}{ }_{\mathrm{U} p} \mathrm{O}$ ogólne schematy dla pytań skwantyfikowanych:

$(*)_{\mathrm{W}} \quad ? A \subset U^{\{\cdots\}}: A \subset\left\{x \in U^{\{\cdots\}}: C^{\{\ldots\}}(\{\ldots\})\right.$ dlatego, $\left.\dot{z} e(x)\right\}$,

$\left.\left({ }^{*}\right)_{\mathrm{U}} \quad ? A \subset U^{\{\cdots\}}: A \subset\left\{x \in U^{\{\cdots\}}: \mathrm{C}^{\{\cdots\}}\right\}^{\prime}(x)\right\}$,

$\left({ }^{*}\right)_{\mathrm{U} i} ? A \subset U_{i}: A \subset\left\{x \in U_{i}: p(x)\right\}$,

$(*)_{\mathrm{U} p} ? A \subset U_{p}: A \subset\left\{x \in U_{p}: p(x)\right\}^{18}$.

\section{A.2 Rodzaje pytań}

Obszerne uwagi do tzw. schematu polskiego i jego potrzebnych uzupełnień uzasadniają zwięzłe odniesienie się do kwestii rodzajów pytań. Otóż zgadzam się z przekonaniem wyrażonym przez prof. J. Wojtysiaka, że „pomimo różnic powierzchniowych” „głęboka” struktura tych pytań jest taka sama ${ }^{19}$. Zgadzałem się z tym poglądem, nim zapoznałem się z uwagami do rodzajów

${ }^{18}$ Aby wskazać na konkretną kwantyfikację, jest dodawany w schemacie warunek co do liczności zbioru $A$, zbędny jedynie dla kwantyfikacji „,wszystkie”, na którą wskazuje znak równości, którym w takiej sytuacji trzeba w powyższych schematach ujednoznacznić symbol $\subset$ (rozumiany w napisach tak, że nie jest wykluczona identyczność). Jest oczywiste, że w schematach tych da się ująć także pytania nieskwantyfikowane (znika warunek dla liczności zbioru). Na marginesie warto odnotować, że wymaganie kwantyfikacyjne powinno być zgodne z licznością uniwersum, np. nie można wymagać podania czterech, gdy ogółem są trzy, albo wyliczenia wszystkich, gdy nie ma żadnych — ale wymóg ten dotyczy kwestii trafności pytań, tu pominiętej.

${ }^{19}$ Zaimek „tych” odsyła w artykule J. Wojtysiaka do konkretnych pytań analizowanych w monografii, pośród których jest pytanie do rozstrzygnięcia, pytanie do wyjaśnienia i dwa pytania do uzupełnienia. 
pytań sformułowanymi w recenzji wydawniczej monografii - w obecnej wypowiedzi J. Wojtysiaka rozbudowanymi, uzasadnionymi oraz zawierającymi zarys rozwiązania alternatywnego do podziału pytań przyjętego w monografii - a świadczy o tym fakt, że schematy stosowane do przedstawiania struktury pytań każdego z wyróżnionych rodzajów - tj. schematy $(*)_{\mathrm{R}},(*)^{\prime}{ }_{\mathrm{W}},(*)_{\mathrm{U}}^{\prime}$ oraz wszystkie ich odmiany, jak $(*)_{\mathrm{U} i}^{\prime},(*)_{\mathrm{U} p}^{\prime},(*)_{\mathrm{U}},(*)_{\mathrm{U} i}$, $(*)_{\mathrm{U} p}$ i inne zaproponowane w monografii — podpadają pod ogólny schemat:

$(*) ? x^{*}$ in $U^{*}: C^{*}\left(x^{*}\right)$.

„Głęboka” struktura jest więc taka sama dla dowolnego pytania. Zgodnie z (*) można powiedzieć, ,że zadaniem odpowiadającego na pytanie jest znalezienie w pewnym zbiorze elementu (zestawu elementów), który spełnia określony warunek". Gdyby się ponadto przyjęło, że pytanie do uzupełnienia to takie, które „wymaga od odpowiadającego uzupełnienia (jak powiedziałaby A. Brożek) luk w naszej wiedzy", wtedy trzeba by także uznać, że „Każde pytanie jest pytaniem do uzupełnienia tak rozumianym”.

Wniosek ten jest jednak uzasadniony tylko na gruncie zacytowanego rozumienia pytań do uzupełnienia. Przytoczona definicja jest pragmatyczna, w części definiującej jest bowiem wskazane zadanie uzupełnienia przez odpowiadającego luki w wiedzy. (Notabene określenie to da się sprowadzić do twierdzenia, że każde pytanie jest do uzupełnienia, ponieważ trzeba na nie odpowiedzieć). Takie rozumienie pytania do uzupełnienia jest nie tylko znacznie szersze od przyjętego w monografii (co oczywiste, bo jest uniwersalne w dziedzinie pytań), lecz nie uwzględnia cech pytań ważniejszych od pragmatycznych ${ }^{20}$.

Z kolei wadą tradycyjnego podziału pytań jest zastosowanie wyłącznie kryteriów syntaktycznych: pytania do rozstrzygnięcia to takie, w których występuje, co najmniej raz, partykuła „Czy”, a pozostałe, tj. do uzupełnienia (zwane też pytaniami dopełnienia), są rozdzielane według tego, czy jest w nich „Dlaczego" - są wtedy pytaniami do wyjaśnienia (problemowymi), a w przeciwnym razie są pytaniami do uzupełnienia zwykłymi (domagają się nie wyjaśnienia, lecz prostego uzupełnienia) ${ }^{21}$.

\footnotetext{
${ }^{20}$ Trafna jest natomiast pragmatyczna definicja zasadności: ma być luka w potrzebnej wiedzy — stwarzająca sytuację pytajną, która wywołuje myśl pytajną wyrażoną w wypowiedzi, badanej w logice za pośrednictwem reprezentującego ją zdania pytajnego - luka uzasadniająca postawienie pytania.

${ }^{21}$ Zob. AjDuKIEwicz 1975, 88. Modyfikacje tego podziału i nowe propozycje wykraczające poza syntaktykę a także innowacje terminologiczne są w JADACKI 2001, 241-244 — decyzyjne, problemowe-przyczynowe, problemowe-celowe, kompletywne; BROżeK 2007, 84-114; 2010
} 
Członami podziału uzasadnionego w monografii są takie same kategorie pytań, lecz wydzielone według poprawionych kryteriów. Przed sformułowaniem i omówieniem tych kryteriów warto przypomnieć przyjęte i stosowane w monografii odróżnienie zdań pytajnych od pytań, tj. zinterpretowanych pytajnych, zdań wziętych w jednym spośród ich możliwych znaczeń. Odróżnienie to odciska jest także na rozumieniu uniwersum. Gdy mowa o zdaniach pytajnych i formułowanych w języku odpowiedziach, wtedy uniwersum jest rozumiane syntaktycznie, tj. jako zbiór wyrażeń (nazw lub zdań), które są podstawiane za zmienną (zmienne) w schemacie odpowiedzi właściwej (który jest fragmentem schematu struktury pytania). Natomiast w uniwersum rozumianym semantycznie są odniesienia tych wyrażeń („odpowiedniki ontologiczne" jak je nazywa J. Wojtysiak), tj. desygnaty nazw lub zdań (stany rzeczy).

Otóż podstawowe i wystarczające kryterium oddzielenia zdań pytajnych i pytań do rozstrzygnięcia od pozostałych jest struktura ich uniwersum, wskazanego w schemacie

$\left({ }^{*}\right)_{\mathrm{R}} \quad ? x \in\{\{\ldots\}, \operatorname{non}\{\ldots\}\}: C^{\{\ldots\}^{\prime}}(x)$.

Chodzi o to, że uniwersum to jest zawsze, dla każdego pytania do rozstrzygnięcia, podzielone dychotomicznie. Podział dychotomiczny jest widoczny wprost $\mathrm{w}$ schemacie struktury takich pytań, bo są w nim tylko dwa elementy wydzielone według: $\{\ldots\}-\operatorname{non}\{\ldots\}$; jest jednak widoczny także w uniwersum wzbogaconym o możliwości ukryte za elementami wyznaczającymi odpowiedzi właściwe. Wzbogacenie dotyczy zwykle elementów ,ukrytych” za non $\{\ldots\}-$ co jest dobrze zilustrowane wynikami analizy pytań opartych na zdaniach pytajnych (1) i (2). Są też jednak takie pytania do rozstrzygnięcie, w których również element uniwersum ,pozytywny”, tj. oznaczony przez $\{\ldots\}$, kryje pewne możliwości. Dla zilustrowania weźmy zdanie pytajne:

(8) Czy Piotr studiuje filozofię lub psychologię?

wzięte, dla uproszczenia ilustracji, w znaczeniu

(8a) Piotr studiuje czy \{filozofię lub psychologie\}?

Struktura tego pytania podpada pod schemat:

$? x \in\{\{\mathrm{F} \vee \mathrm{P}\}$, non $\{\mathrm{F} \vee \mathrm{P}\}\}:$ Piotr studiuje $(x)$,

kompletywne, konfirmatywne, selektywne oraz w BROżEK 2008, 147-152 - kompletywne, augmentatywne, kwalifikatywne, predykatywne, problemowe-kauzalne, problemowe-teliczne. 
a $\mathrm{w}$ rozwiniętym uniwersum są możliwości $\{\langle\mathrm{F}, \mathrm{P}\rangle,\langle n \mathrm{~F}, \mathrm{P}\rangle,\langle\mathrm{F}, n \mathrm{P}\rangle ;\langle n \mathrm{~F}$, $n \mathrm{P}\rangle\}$, spośród których pierwsze trzy są ,pozytywne” i pojawiają się w jednej spośród trzech pełnych odpowiedzi twierdzących, czyli są „ukryte” za niepełną odpowiedzią właściwą Tak, tj. Piotr studiuje filozofię lub psychologię.

Dla sprawy podziału pytań najważniejsze jest właśnie to, że uniwersum każdego pytania do rozstrzygnięcia jest podzielone dychotomicznie, tj. podzielone na dwa człony i w oparciu o sprzeczność. Przejawia się to tym, że na każde pytanie do rozstrzygnięcia są dokładnie dwie odpowiedzi właściwe, reprezentowane przez Tak albo Nie, wskutek czego pytania takie nie mogą być - w przeciwieństwie do pytań do uzupełnienia problemowych i zwykłych - wieloznaczne kwantyfikacyjnie. Ponadto - i to także jest cecha wyróżniająca - uniwersum każdego pytania do rozstrzygnięcia jest wyznaczone wyłącznie przez odpowiadające mu zdanie pytajne i przyjęty w pytaniu podział składników osnowy na zakładane i kwestionowane. Takie cechy - a nie samo użycie, wprost albo domyślne, w zdaniu pytajnym partykuły „Czy” — są konieczne i wystarczające do uznania dowolnego pytania za pytanie do rozstrzygnięcia.

Różnice w stosowaniu kryterium syntaktycznego oraz semantycznego dobrze ilustruje zdanie pytajne:

(9) Piotr studiuje filozofię, psychologię czy matematykę?

Jest w nim użyta partykuła „czy”, lecz w taki sposób, że i to zdanie, i oparte na nim pytania nie należą do kategorii do rozstrzygnięcia, nie da się bowiem odpowiedzieć na nie właściwie: Tak bądź Nie. Zdanie pytajne (9) jest rodzaju do uzupełnienia, co staje się widoczne, gdy się je sformułuje inaczej (niektóre składniki osnowy są oznaczone skrótami):

(9a) Który kierunek spośród $\{F, P, M\}$ studiuje Piotr?

Zdanie pytajne (9a) ujednoznacznione np. zgodnie z kwantyfikacją „wszystkie" ma strukturę

$? A \subset\{\mathrm{F}, \mathrm{P}, \mathrm{M}\}: A=\{x \in\{\mathrm{F}, \mathrm{P}, \mathrm{M}\}:$ Piotr studiuje $(x)\}$.

Do zdań pytajnych do rozstrzygnięcia należy natomiast:

(10) Czy Piotr studiuje F albo P albo M?

Zdanie to, odczytane jako pytanie:

(10a) Piotr studiuje czy $\{F$ albo $P$ albo $M\}$ 
podpada pod schemat (zapis uproszczony):

$? x \in\{<\mathrm{F}, \mathrm{P}, \mathrm{M}>$, non $<\mathrm{F}, \mathrm{P}, \mathrm{M}>\}$ : Piotr studiuje $(x)$,

a dopowiedzi właściwe to Tak, Piotr studiuje filozofię albo psychologię albo matematyke oraz Nie, rozumiane jako Piotr studiuje, lecz nie: filozofię albo psychologię albo matematykę. Pełną (niewłaściwą) odpowiedzią twierdzącą jest np. Piotr studiuje tylko psychologię, a pełną (również niewłaściwą) przeczącą odpowiedzią jest np. Piotr nie studiuje filozofii, lecz studiuje psychologie i matematykę.

Jeśli chodzi o oddzielenie zdań/pytań do uzupełnienia problemowych od pozostałych, zwanych do uzupełnienia zwykłymi, to w pierwszej podkategorii są te, w których członie pytajnym jest użyty przyimek "dlaczego" lub inny zwrot, który da się tym słowem zastąpić, np. „Co było powodem ...”, Po co ..." itp. Kryterium podziału oparte na ,jest użyte” jest czysto syntaktyczne, dodanie „lub da się tym słowem zastąpić” sprawia jednak, że przestaje takie być; ponadto zasada podziału przestaje być ostra, a zmniejszanie nieostrości wymaga uściśleń warunku „da się zastąpić”. Wada tak określonej zasady ukazuje się wyraźnie, gdy zdanie pytajne do wyjaśnienia zinterpretuje się przyczynowo albo celowościowo. Przyjąwszy, że człon pytajny odnosi się do całej osnowy $p=$ Piotr wyemigrowat oraz że nie jest tu istotna sprawa kwantyfikacji pragmatycznej, porównajmy pytania:

(10) Dlaczego Piotr wyemigrowat?

(10a) Co byto powodem tego, że Piotr wyemigrowat?

(10b) Co byto celem tego, że Piotr wyemigrowat?

(10c) Jak to sie stato, że Piotr wyemigrowat?

Wedle kryterium czysto syntaktycznego tylko (10) jest pytaniem do wyjaśnienia. Zgodnie $\mathrm{z}$ kryteriami stosowanymi w monografii i zaproponowanymi w niej schematami struktury pytań, również (10a) i (10b) to pytania do uzupełnienia problemowe. Pierwsze podpada pod formułę dla pytań problemowych kauzalnych

$\left({ }^{*}\right)^{\prime}{ }_{\mathrm{wp}} \quad ? x$ in $U^{\{\ldots\}}$ : Powodem tego, że $C^{\{\ldots\}^{\prime}}(\{\ldots\})$ byto to, że/byto $(x)$,

a drugie pod schemat dla pytań do wyjaśnienia celowościowych

$(*)^{\prime}{ }_{\text {wc }}$ ? $x$ in $U^{\{\cdots\}}$ : Celem tego, że $C^{\{\ldots\}^{\prime}}(\{\ldots\})$ byto to, ze elbyto $(x)$.

Natomiast pytanie (10c) jest pytaniem do uzupełnienia nieproblemowym, w którym człon odnosi się do całej osnowy, jest więc takiego samego 
rodzaju, jak analizowane wyżej zdanie pytajne do uzupełnienia oznaczone jako (5e). Pytanie (10c) ma strukturę

$? x \in U_{p}$ : to, że $p$ stało się tak, że $(x)$,

czyli podpada pod schemat:

$\left({ }^{*}\right)^{\prime}{ }_{\mathrm{U} p} ? x \in U_{p}: p(x)$.

Również J. Wojtysiak zwrócił uwagę na podobieństwo zdań pytajnych/ pytań, których człon pytajny odnosi się do całej osnowy. Nie jest jednak trafne stwierdzenie, że $\mathrm{w}$ podziale przeprowadzony według zasady: [czy chodzi w pytaniu o - ] „uzupełnienie całej osnowy” albo „uzupełnienie jej fragmentu" - w kategorii pierwszej znalazłoby się (wszystkie, jak wynika z kontekstu) „pytania do rozstrzygnięcia, pytania problemowe oraz niektóre 'stare' pytania do uzupełnienia (np. pytania jak) [...], a większość 'starych' pytań do uzupełnienia w drugiej grupie”. Nie jest trafne, ponieważ w wielu pytaniach do rozstrzygnięcia i do wyjaśnienia człon pytajny nie odnosi się do całej osnowy, co zmusiłoby do rozdzielania ogółu pytań do rozstrzygnięcia i ogółu pytań do wyjaśnienia na kategorie „cała osnowa” vs „fragment osnowy" - a więc do podziału wyraźnie sztucznego, zwłaszcza w kategorii pytań do rozstrzygnięcia. Ponadto nie jest dobrze dobrany przykład pytania, które przytacza J. Wojtysiak, a które ma ilustrować odnoszenie się niektórych pytań do uzupełnienia do całej osnowy. Chodzi o pytanie - w monografii (3b) - Jak Kolumb odkryt Ameryke w roku 1492?. Pytanie to — i tak jest w monografii zaklasyfikowane — podpada nie pod wyżej przypomniany schemat $(*)_{\mathrm{U} p}$, lecz ma strukturę ? $x \in U_{2}: p(x)$, a formuła ta wskazuje, że w uniwersum $U_{2}$ są wyrażenia odnoszące się do drugiego składnika osnowy tego pytania (jak odkrył?), np. przysłówki takie, jak przypadkowo, niespodziewanie, szybko. Struktura tego pytania jest więc zgodna ze schematem:

$\left({ }^{*}\right)^{\prime}{ }_{\mathrm{U} i} ? x \in U_{i}: p(x)$.

Przykładem dobrze ilustrującym odnoszenie się do całej osnowy jest pytanie (3d) z monografii, tj. Jak to się stało/Jak doszło do tego, że Kolumb odkryt Ameryke w roku 1492?, tj. pytanie o strukturze zgodnej z formułą:

$(*)^{\prime}{ }_{\mathrm{U} p} ? x \in U_{p}: p(x)$.

Jest zatem tak, że nie ma ostrej granicy między pytaniami problemowymi a innymi pytaniami do uzupełnienia (domagające się prostego uzupełnienia, jak nazywał pytania tej kategorii S. Kamiński). Pytania „Dlaczego”, pod- 
padające pod schemat $(*)^{\prime}$ w, można wyrazić w formie kauzalnej i celowościowej, tj. zgodnie $z$ formułami $\left({ }^{*}\right)^{\prime} w_{p} i\left({ }^{*}\right)^{\prime} w_{c}$, a zdania pytajne o przyczynę lub cel nawet bez przeformułowywania mogą być odczytywane tak, że podpadają pod schemat $\left({ }^{*}\right)^{\prime}{ }_{\mathrm{U} p}$, ujmujący strukturę pewnej podklasy pytań do uzupełnienia - i odwrotnie. Odnośnie do tego przechodzenia od pytań „Dlaczego" przez pytania do wyjaśnienia kauzalne lub celowościowe do pytań do uzupełnienia może się pojawić wątpliwość, czy zastąpienie „Dlaczego” przez inny człon pytajny nie zmienia znaczenia zdania pytajnego, a wskutek tego zmienia uniwersum, z którego są czerpane wyjaśnienia, tj. powody lub/ albo cele. By takie wątpliwości usunąć, trzeba by, powtórzę, uściślić warunek „da się zastąpić” (na przykład wymogiem, że w wyniku zastąpienia nie zmienia się uniwersum).

Nieostrość tego podziału drugiego rzędu, tj. pytań do uzupełnienia na problemowe i pozostałe - którą komentowałem i ilustrowałem również w monografii - nie uzasadnia jednak oceny, że wadliwy logicznie jest podział pytań podstawowy, tj. na pytania do rozstrzygnięcia i pozostałe, tj. do uzupełnienia. Oceny tej nie wspierają także zawarte w monografii (JONKISZ 2020b, 110) uwagi o „obustronnych przejściach”, do których odsyła J. Wojtysiak. Gdy bowiem mowa tam o „obustronnych przejściach”, to nie chodzi o to, że dane pytanie można zaklasyfikować i do kategorii do rozstrzygnięcia, i do rodzaju do uzupełnienia. Nieostrość klasyfikacji, wyżej omówiona, jest widoczna w przypadku niektórych pytań do uzupełnienia i dotyczy ich podziału na problemowe i pozostałe. Natomiast granica oddzielająca pytania do rozstrzygnięcia jest ostra (zasadę podziału przypomniałem wyżej), a gdy mowa w monografii o „obustronnych przejściach”, chodzi o szczególne sytuacje: stawiania pytań do uzupełnienia o skrajnie zawężonym zakresie oraz o pytania do rozstrzygnięcia sformułowane tak, że jest w nich dwukrotnie użyta partykuła „czy”. Jeśli chodzi o pierwszą sytuację, to można pytać na przykład (pomijam niejednoznaczność kwantyfikacji):

(11) Która spośród liczb zbioru A jest parzysta?

Zadawanie takiego pytania jako pytania do uzupełnienia jest celowe, o ile w zbiorze $A$ są co najmniej dwie liczby ${ }^{22}$. W sytuacji skrajnej, na przykład:

(11a) Która spośród liczb zbioru \{4\} jest parzysta?

\footnotetext{
${ }^{22}$ Pomijam możliwą nietrafność pytania (rozumianą jak w monografii), spowodowaną np. tym, że w zbiorze są wyłącznie liczby parzyste.
} 
pytanie do uzupełnienia powinno jednak być zastąpione pytaniem do rozstrzygnięcia:

(11b) Czy liczba 4 jest parzysta?

Dla zilustrowania „przejścia” odwrotnego, rozważmy zdanie pytajne

(12) Czy Piotr studiuje filozofię?

Odczytane jako pytanie:

(12a) Piotr studiuje czy \{filozofie\}?.

podpada pod schemat (trochę uproszczony):

$? x \in\{\mathrm{F}, n \mathrm{~F}\}:\{\mathrm{P}, \mathrm{s}\}(x)$

Pytanie to jednak może być - i bywa - wyrażone inaczej:

(12b) Jeśli Pior studiuje, to czy filozofię, czy nie filozofię?

lub

(12c) Co Piotr studiuje, filozofię czy nie filozofię?

Pytanie (12c) można bez partykuły „czy” równoważnie wyrazić w pytaniu, co do którego nie ma już wątpliwości, że należy do pytań do uzupełnienia:

(12d) Co spośród \{filozofia, nie filozofia\} Piotr studiuje?

$\mathrm{Na}$ to ostatnie pytanie, tak samo jak na (12b) i (12c), nie da się odpowiedzieć (w sposób właściwy) Tak/Nie - i to jest zasadnicza (kryterialna) różnica. Obok tej podstawowej różnicy warto także zauważyć, że w schemacie tego ostatniego pytania, tj. w:

$? x \in\{\mathrm{F}, \mathrm{nF}\}:$ Piotr studiuje $(x)$,

jest symbol negacji przednazwowej, a w schemacie dla (12a) jest użyty skrót dla negacji non. Różnica ta jest ogólnie bardzo ważna (w interpretacji odpowiedzi negatywnej na pytania do rozstrzygnięcia), w kontekście porównywania pytań (12a) i (12d) nie wpływa jednak ani na wartość logiczną odpowiedzi właściwych na oba pytania, ani na warunki ich trafności (pytania takie, co podkreślałem także w monografii, są równoważne). Można bowiem równoważnie powiedzieć, że pośród przedmiotów studiowanych przez Piotra nie ma filozofii (rozumienie odpowiedzi przeczącej na 12a) albo że Piotr studiuje nie-filozofię (odpowiedź przecząca na 12d). 
Gdy zatem mowa o „przechodzeniu”, chodzi jedynie o potrzebę zastąpienia wadliwego pytania pytaniem innej kategorii lub o możliwość takiego przeformułowania pytania, by znalazło się w innej kategorii - czyli o względy pragmatyczne, a nie o nieostrość granicy między tymi kategoriami wydzielonymi według kryteriów syntaktycznych i semantycznych.

Pozostaję więc przy podziale wywodzącym się z prac Ajdukiewicza, choć przeprowadzonym według poprawionych kryteriów, godząc się przy tym na nieostrość dalszego podziału w obrębie pytań do uzupełnienia. Jest przy tym oczywiste, że pytania można podzielić według wielu innych kryteriów (niektóre uwzględniłem w końcowym rozdziale monografii). Przyjęte w monografii, tu dyskutowane kryteria uznaję za trafne, a przeprowadzony według nich podstawowy podział pytań za poprawny logicznie oraz jednorodny i naturalny. Te pierwsze trzy własności są zapewnione przez dychotomiczność podziału ogółu pytań na do rozstrzygnięcia i pozostałe. Jest także naturalny, ponieważ został oparty na istotnych, semantycznych własnościach pytań: determinowanie uniwersum przez pytanie, dychotomiczny podział elementów uniwersum, dwie odpowiedzi właściwe wzajemnie sprzeczne; własności te przejawiają się także cechami pragmatycznymi, zwłaszcza tym, że Tak? oraz Nie są uznawane za odpowiedzi właściwe, za naturalne. Można, co oczywiste, uznać wszystkie pytania za do uzupełnienia na podstawie ich cechy pragmatycznej, a następnie podzielić je ze względu na „liczbę lub ontyczną swoistość elementów uniwersum”, podobnie jak według kryteriów czysto syntaktycznych, np. według tego, jaka partykuła albo jaki zaimek jest rdzeniem członu pytajnego itd. Kryteria przyjmowane w takich podziałach nie są jednak pierwszorzędnymi cechami pytań oraz nie są oparte na zasadach tak ostrych i naturalnych, jak zastosowane w monografii.

\section{A.3 TRAFNOŚĆ PYTAŃ}

W swojej wypowiedzi J. Wojtysiak odniósł się do zaproponowanej w monografii koncepcji trafności pytań. Sformułowane przez niego uwagi dotyczą związku między trafnością pytań do uzupełnienia (zwykłych) oraz do wyjaśniania a wartością logiczną założeń pytania. Pierwsza spośród nich jest ważna dla udowodnionego w monografii twierdzenia, że trafność pytania do uzupełnienia gwarantuje, że prawdziwe są jego założenia, lecz nie odwrotnie ${ }^{23}$.

\footnotetext{
${ }^{23} \mathrm{~W}$ dowodzie jest użyte pojęcie trafności uściślone zgodnie z Ajdukiewicza rozumieniem „właściwego postawienia” pytania oraz jest uściślona definicja założenia pytanie (założenia bezpośredniego i dalszych).
} 
Mówiąc dokładniej, uwaga ta dotyczy kontrprzypadku, tj. przykładu okazującego, że nie zachodzi wynikanie odwrotne. Chodzi o pytanie (oznaczone w monografii jako 24a) Która spośród liczb 2, 4, 6 jest parzysta?. Założenie tego pytanie, tj. że jest pośród wyliczonych liczba parzysta, jest prawdziwe, a mimo to pytanie nie jest trafne - o ile trafność jest rozumiana w sposób przyjęty w monografii. J. Wojtysiak nie kwestionuje tej ogólnej prawidłowości, ocenia jednak, że przykład ten jest wynikiem „sztucznego zawężenia uniwersum pytania”. Sądzę jednak, że są sytuacje pytajne, w których pytania o podobnie, a nawet bardziej zawężonym uniwersum są naturalne, na przykład kierowane do ucznia pytanie Czy 4 jest liczba parzysta? Z tego samego powodu jest nietrafne skierowane do studentów pytanie o to, kto spośród nich ma maturę (odrębną kwestią jest zasadność tego pytania).

Zgadzam się natomiast ze stwierdzeniem, że „nietrafnymi, a o prawdziwych założeniach, mogą być także pytania do wyjaśnienia”. W analizach zawartych w monografii przyjąłem, że w uniwersum każdego pytania do wyjaśnienia — „każdego”, bo twierdzenie oznaczone w monografii jako (T2) jest ogólne - jeśli jest jakaś prawdziwe zdanie wyjaśniające, to jest też zdanie wyjaśniające fałszywe, mianowicie negacja jakiegoś wyjaśnienia prawdziwego (oczywiście, mogą być także wyjaśnienia fałszywe niebędące negacjami prawdziwych). Nawet jeśli założenie to jest w przypadku niektórych pytań „sztuczne”, jak je ocenia J. Wojtysiak (miałem i nadal podzielam tę wątpliwość), to jestem skłonny przyjąć, że negacja któregoś z wyjaśnień prawdziwych zawsze może być dołączona do uniwersum pytania do wyjaśnienia - o ile nie jest ono celowo, sztucznie zawężone. Przyznaję jednak, że da się tak zawęzić uniwersum dla pytania do wyjaśnienia, że znajdują się $\mathrm{w}$ nich wyłącznie takie możliwości - w uniwersum rozumianym syntaktycznie: zdania lub nazwy, zależnie od stylizacji pytania i odpowiedzi które dają odpowiedzi prawdzie. Na pytanie o tak zawężonym uniwersum nie da się udzielić fałszywej odpowiedzi właściwej, a możliwość sformułowania takiej odpowiedzi jest koniecznym warunkiem trafności rozumianej zgodnie z Ajdukiewiczem; nietrafne byłoby też pytanie o uniwersum zawężonym wyłącznie do odpowiedzi fałszywych.

Zgadzając się z tym, że da się skonstruować (celowo używam tego słowa) uniwersum pytania do wyjaśnienia tak, by odpowiedzi właściwe ograniczyć wyłącznie do prawdziwych (albo wyłącznie do fałszywych), mam jednak wątpliwości co do tego, czy zawężenie takie jest naturalne. Rozważając różnorodne przykłady pytań oraz wyobrażając sobie możliwe kontrprzypadki dla twierdzeń wyrażających ogólne związki między prawdziwością założeń 
a trafnością pytań do wyjaśnienia, nie uwzględniłem takiej możliwości. Przypuszczam teraz, że głównie z tego powodu, że pytania do wyjaśnienia są zwykle stawiane jako pytania o uniwersum otwartym, praktycznie nieograniczonym, a na pewno ograniczanym rzadziej, niż w przypadku nieproblemowych pytań do uzupełnienia, nie mówiąc o pytaniach do rozstrzygnięcia, których uniwersum jest zawsze ograniczone. Można powiedzieć, że z naturą pytań do wyjaśnienia nie jest zgodne ograniczenie uniwersum do zdań wyłącznie prawdziwych, na co wskazuje także nazywanie takich pytań problemowymi. Kolejna wątpliwość jest mocniejsza: czy pytania o tak ograniczonym uniwersum nadal są pytaniami do wyjaśnienia, czy też pytaniami do uzupełnienia (zwykłymi), które w formie takich zdań pytajnych powinny być formułowane?

Mimo tych wątpliwości zgadzam się z tym, że jest do wyobrażenia sytuacja pytajna, w której uniwersum zdania pytajnego do wyjaśnienia jest tak właśnie ograniczone (pytania dydaktyczne, egzaminacyjne, konkursowe?). Uwzględniając tę możliwość jestem skłonny uzupełnić twierdzenie dotyczące pytań problemowych (w monografii oznaczone jako T2) takim samym warunkiem, jak twierdzenie dla pytań do uzupełnienia (T3). Rezygnując z języka używanego w monografii, można powiedzieć, że zgodnie z tak osłabionym twierdzeniem: jeżeli założenia pytania problemowego są prawdziwe oraz jego uniwersum nie jest identyczne $\mathrm{z}$ możliwościami fundującymi wyłącznie odpowiedzi prawdziwe, to pytanie do wyjaśnienia jest trafne. Pragnę przy tym (z zadowoleniem) zauważyć - co odnotował także J. Wojtysiak — że modyfikacja ta potwierdza stosowany w monografii, dychotomiczny podział pytań: również w kontekście trafności pytania problemowe mają własności takie same, jak pytania do uzupełnienia zwykłe, czyli tworzą z nimi kategorię różną także pod tym względem od pytań do rozstrzygnięcia, dla których obowiązuje twierdzenie mocniejsze: trafność wtedy i tylko, gdy założenia prawdziwe. Modyfikacja taka dostarcza także potwierdzenia „hipotezy o pokrewieństwie tzw. pytań do wyjaśnienia i tzw. pytań do uzupełnienia (lub mocniej: że z pewnego istotnego punktu widzenia zbiór pierwszych zawiera się w zbiorze drugich)". Uzasadniony w monografii podział pytań, w którym problemowe są podkategorią ogólnie rozumianych pytań do uzupełnienia, jest z hipotezą J. Wojtysiaka zgodny. 


\section{B. UWAGI METODOLOGICZNE}

W tej części odnoszę się do uwag dotyczących zastosowanej w monografii metody analizowania zdań pytajnych, do tzw. uogólnionej negacji non, użytej do badania pytań do rozstrzygnięcia, a także do uwag na temat metod filozofowania.

\section{B.1 METODA „SKŁADNIKOWO-KOMBINATORYCZNA”}

Nazwa „składnikowo-kombinatoryczna”, wzięta z uwag J. Wojtysiaka, dobrze wskazuje cechy metody analizowania zdań pytajnych zastosowanej w monografii. Wobec trafnych, a przy tym zwięzłych opisów tej metody zawartych w wypowiedziach uczestników dyskusji (A. Brożek, J. Wojtysiaka, M. Lechniaka) oraz wielu przykładów jej zastosowania w pierwszej części niniejszego artykułu wystarczy tu stwierdzić, że polega ona na (i) reprezentowaniu wyrażenia, które jest osnową pytania, zbiorem jego składników; oraz (ii) badaniu możliwych znaczeń zdania pytajnego - czyli możliwych pytań opartych na danym zdaniu — przy czym znaczenia te (i pytania) są reprezentowane możliwymi podziałami składników osnowy na kwestionowane ( $\mathrm{w}$ zasięgu członu pytajnego) oraz pozostałe, tj. zakładane $\mathrm{w}$ danym pytaniu, czyli możliwymi kombinacjami zestawianymi z podstawowego zbioru składników osnowy.

Jeśli chodzi o krok (i), to trafna jest uwaga (M. Lechniaka), że: „nie możemy po prostu przyjąć, że zdanie składa sie z jakichkolwiek składników $e_{1}, e_{2}, \ldots, e_{k}$. Wtedy bowiem musielibyśmy uznać za zdanie np. zbiór $\{$ Kolumb, Magellan, Cook, $\}$ czy $\{$ odkryt, zdobyt, zagubil\} — muszą jakieś wymagania składniowe zostać przyjęte, np. że na zdanie składa się minimum podmiot (nazwa) i orzeczenie (predykat), a zatem, że w zdaniu są co najmniej dwa różne elementy (i dwa różne obiekty będące ich korelatami semantycznymi)". Uwaga jest trafna ${ }^{24}$, rzecz jednak w tym, że nie przyjmuję założenia, o którym w niej mowa. W analizach zawartych w monografii nie zakładam, że da się w ten sposób reprezentować dowolne zdanie, a tym bardziej, że dowolny ciąg wyrazów tworzy zdanie. W rozważaniach ogólnych zakładam, że osnową dowolnego zdania pytajnego jest wyrażenie o składnikach $e_{1}, e_{2}, \ldots, e_{k}$, a gdy — dla sprawdzenia trafności ustaleń ogólnych — są analizowane

\footnotetext{
${ }^{24}$ Pomijam kwestie mniej tu ważne, np. że wyrażenie tworzące osnowę nie musi być co najmniej dwuelementowe, jak np. w pytaniu Czy pada?
} 
konkretne zdania pytajne, wtedy ich osnowy (zastane, poprawnie sformułowane) są w ten sposób przedstawiane. Co więcej, ten sposób reprezentowania osnowy nie jest niezbędny, choć jego zastosowanie znacznie upraszcza analizy, tj. skraca napisy, ułatwia wyróżnianie możliwych kombinacji oraz przekładanie znaczeń uzyskanych pytań i odpowiedzi na język teoriomnogościowy. Mówiąc krótko, metoda „składnikowa” jest stosowana w ramach logicznego rekonstruowania pytań i odpowiedzi formułowanych w języku naturalnym, w rzeczywistych sytuacjach pytajnych; a w sytuacjach porozumiewania się nie pojawiają się takie pytania, których osnowy dałoby się poprawnie reprezentować np. zbiorem \{Kolumb, Magellan, Cook\}.

Oznaczenie składników osnowy skrótami literowymi albo liczbowymi nie zmienia ich oryginalnej funkcji składniowej (ich kategorie składniowe nie „zostają w konstrukcji Jonkisza zrównane”). A przy tym podział oryginalnej osnowy na uwzględnione $\mathrm{w}$ analizie jej składniki nie musi, choć może, sięgać aż do składników elementarnych — określonych trafnie przez J. Wojtysiaka jako jednostki osnowy znaczące; analizując zdania pytajne można, dla uproszczenia, nie rozkładać składników takich np., jak „w roku 1492” na „w” (choć sensowne jest także „przed”, „po”, „około”) i „roku 1492”.

W wypowiedziach uczestników dyskusji są także komentarze dotyczące (ii), tj. stosowania metody „kombinatorycznej” — także takie, w których są wskazane wady tej metody: jej „mechaniczne stosowanie” niekiedy zawodzi (J. Wojtysiak); konsekwentne stosowanie ociera się o granice sztuczności (M. Lechniak); [stosujący ją] „dopuszcza [...] każdorazowo wszelkie kombinacje zakładanych i kwestionowanych elementów. Tym samym dopuszcza istnienie takich odmian pytań, które nie występują np. w języku polskim, a może nawet w żadnym istniejącym języku naturalnym" (A. Brożek).

Jako przykład błędu spowodowanego „mechanicznym stosowaniem” J. Wojtysiak podaje wyniki analizy możliwych znaczeń zdania pytajnego (12a w monografii): „Czy neutrino istnieje?” Otóż wybierając ten przykład do analizy, chciałem nawiązać do pytań niegdyś bardzo zasadnych w nauce, takich np. jak: „Czy istnieje perpetuum mobile?”, „Czy istnieją czarne dziury”, „Czy istnieje bozon Higgsa?”. Przykład ten jednak, o ile miał ilustrować potrzebę wyróżniania wszystkich znaczeń możliwych metodą „kombinatoryczną", to, przyznaję, został źle dobrany, ponieważ w kontekście tego pytania celowe jest tylko takie odczytanie, które wymaga rozstrzygania, czy taka cząstka istnieje. Zgadzam się także z potrzebą odróżniania w takich analizach istniejeljest egzystencjalnego, od — można powiedzieć — przysłówkowego (istnieje fizycznie, istnieje tu i teraz etc.), choć dostrzegam 
względność takiego podziału. Dlatego - zauważywszy trudności w wysłowieniu różnic znaczeniowych między pytaniami opartymi na (12a) - wskazałem zdanie pytajne: „Czy Jan (tu, teraz) jest?” jako przykład, w którym są wyraźne różnice znaczeniowe między sytuacjami i odpowiedziami reprezentowanymi w stosowanej metodzie przez układy: $\{n J, \mathrm{j}\},\{J, n \mathrm{j}\},\{n J, n \mathrm{j}\}$. Wątpliwość co do tych różnic znaczeniowych wyraża jednak J. Wojtysiak (do przykładu tego, sprawozdawczo, odnosi się również M. Lechniak), a chodzi o zdania $\{J, n \mathrm{j}\},\{n J, n \mathrm{j}\}$, których znaczenia trudno uchwycić (,nie rozumie"). Sądzę jednak, że gdy ,jest” rozumie się nie egzystencjalnie, lecz „lokalnie" — na co wyraźnie wskazują wtrącenia dodane w nawiasie wtedy odpowiadające tym schematom odpowiedzi, podane jako przykładowe w monografii, dobrze wskazują na te różnice (tak samo jak czasownik „medytuje” w przykładzie J. Wojtysiaka).

Co do sztuczności, to zgadzam się i z tym, że wyróżnianie wszystkich „kombinatorycznie” możliwych znaczeń w przypadku każdego zdania pytajnego może prowadzić do wskazywania sztucznych jego znaczeń, czyli sztucznych pytań. Na zarzut sztuczności narażone są zwłaszcza analizy takie, jak w monografii. Mają bowiem pokazywać na konkretnych przykładach, jak metodę składnikowo-kombinatoryczną stosować do zdań pytajnych, co wymaga wyróżniania wszystkich możliwych znaczeń; zdania te są jednak analizowane w oderwaniu od sytuacji pytajnych, wskutek czego niektóre spośród możliwości wyglądają na sztuczne, choć w konkretnych sytuacjach są naturalne. By zilustrować zagrożenie sztucznością, M. Lechniak wylicza możliwe znaczenia zdania pytajnego:

\section{„Czy Kolumb jest żeglarzem?”}

i pyta, czym różni się osnowa $\{1,2,3\}$ od „osnowy” $\{1,3\}$, a poprawnie jest powiedzieć - kwestionowanie całej osnowy tego zdania, tj. składników $\{1,2,3\}$, od kwestionowania składników $\{1,3\}$.

Pozostając na gruncie omawianej teraz metody, można na tę wątpliwość ściśle odpowiedzieć. Zacytowane zdanie pytajne ma siedem możliwych znaczeń (notabene: wyliczając je, M. Lechniak pominął odczytanie Kolumb żeglarzem czy jest?), wskutek czego taka sama wieloznaczność dotyka także przeczącej odpowiedzi na pytanie Czy Kolumb jest żeglarzem?, natomiast za odpowiedzią przeczącą na pytanie Jest czy Kolumb żeglarzem? są spośród tych siedmiu ukryte tylko trzy odpowiedzi jednoznaczne, tj. $\{\mathrm{j}, n \mathrm{~K}, \dot{\mathrm{Z}}\},\{\mathrm{j}, \mathrm{K}$, $n \dot{Z}\},\{\mathrm{j}, n \mathrm{~K}, n \dot{Z}\}$. Odpowiedź taka nie zadowoli jednak zarzucającego sztuczność, bo w zarzucie tym chodzi o to, czy w ogóle warto stosować tę metodę 
do analizowania pytań, skoro wyróżnione w niej możliwości często nie mają odpowiednika w rozumieniu zdania pytajnego w rzeczywistej sytuacji.

Otóż nadal jestem przekonany, że w ogólnej analizie logicznej trzeba wskazać wszystkie możliwe znaczenia, niezależnie od tego, w jakich konkretnych sytuacjach stają się one aktualne. Rozważmy pytanie:

(13a) Kolumb żeglarzem czy jest?

- wybrane spośród możliwych interpretacji zdania (13) dlatego, że wydaje się szczególnie sztuczne i odnosi się wprost do propozycji M. Lechniaka, by „jako składnik [...] brać całe orzeczenie imienne, a nie osobno łącznik 'jest' i osobno orzecznik". W pytaniu tym związek Kolumba z żeglowaniem jest zakładany, pytanie dotyczy tego, czy jest Kolumb żeglarzem. Otóż pytanie (13a) byłoby (było?) aktualne (naturalne) na przykład w sytuacji, gdy pytający chce się dowiedzieć, czy szkolony w żeglowaniu (młody) Kolumb już jest żeglarzem, czy też za jakiś czas można go będzie za żeglarza uznać; albo w sytuacji, gdy jest wątpliwość co do tego, czy (stary) Kolumb nadal jest żeglarzem.

W analizach ukierunkowanych na wykrycie ogólnych prawidłowości dotyczących pytań i odpowiedzi, takich jak w monografii, metoda wyróżniania wszystkich możliwych znaczeń jest niezbędna, nie są natomiast niezbędne opisy sytuacji, w których każde ze znaczeń możliwych byłoby/jest aktualne. Jeśli natomiast chodzi o zastosowania samej metody składnikowo-kombinatorycznej do analizowania konkretnych pytań, to na pewno pozwala ona wskazać i uściślić te spośród ogółu znaczeń możliwych, które w danej sytuacji lub dla potrzeb analizy (np. filozoficznej) chce się lub trzeba uwzględnić.

\section{B.2 UOGÓLNIONA NEGACJA}

Gdyby zdania pytajne „Czy $p$ ?” były zawsze rozumiane tak, że partykuła „,czy” odnosi się do całej osnowy $p$, wtedy tzw. uogólniona negacja nie byłaby potrzebna, ponieważ znaczenie (warunki prawdziwości) odpowiedzi przeczącej $\sim p$ oddaje negacja zwykła, tj. przedzdaniowa. Ponieważ jednak tak nie jest - co od dawna jest dostrzegane, a w analizach zawartych w monografii zostało w sposób ogólny opisane — więc jest potrzebne pojęcie negacji, które da się stosować także wtedy, gdy kwestionowana w pytaniu, a negowana $\mathrm{w}$ odpowiedzi jest nie cała osnowa. W tym celu została zdefiniowana tzw. uogólniona negacja non - i to już w analizach poświę- 
conych strukturze pytań, ponieważ w schemacie dla pytań do rozstrzygnięcia była potrzeba zaznaczenia takiego „częściowego” kwestionowania i negowania, zarówno w formule ukazującej uniwersum pytania, jak i - konsekwentnie - w członie określającym budowę odpowiedzi właściwej.

Negacja non jest następnie stosowana w monografii do analizowania znaczeń odpowiedzi przeczących na pytania do rozstrzygnięcia oraz do uściślenia warunków prawdziwości dla takich odpowiedzi. Wyniki trafnej analizy tych pytań powinny potwierdzić, że, po pierwsze, z każdego spośród wyróżnionych z użyciem negacji non znaczeń odpowiedzi przeczącej wynika negacja odpowiedzi twierdzącej, a przy tym - co było dla mnie szczególnie ważne - znaczenia te, sformułowane w języku teorii mnogości, muszą być zgodne z tym, jak odpowiedzi są rozumiane w sytuacjach pytajnych, w których odpowiedzi są formułowane w języku naturalnym. Po drugie, za konieczny uznałem także warunek, by negacja non zastosowana do całej osnowy była równoważnie wymienna $\mathrm{z}$ negacją przedzdaniową, tj. by było tak, że $\sim p \Leftrightarrow$ non $p$. Wymagania te spełnia pojęcie zdefiniowane w monografii w D2 oraz jego uogólnienie określone w D3. Negacja non jest zatem zwana uogólnioną i dlatego, że jest stosowalna nie tylko do całej osnowy, lecz także do jej dowolnych członów, aż do pojedynczych składników; jak i na podstawie jej zgodności (równoważności) z negacją $\sim$ w sytuacji skrajnej, tj. negowania całej osnowy.

Uwagi do pojęcia uogólnionej negacji sformułował M. Lechniak. Dostrzegając szerszy niż dla nagacji zakres stosowania non: [Jest stosowana] (1) „zarówno do całych zdań, jak i do ich niezdaniowych składników, czy składników tych składników" - skłania się jednak ostatecznie do stwierdzenia: (2), ,[...] że jest to zwykła negacja zdaniowa, tylko zagnieżdżona w odpowiadających poszczególnym predykatom zdaniach atomicznych".

Zgadzając się z główną myślą pierwszej z tych wypowiedzi, muszę jednak dodać ważną uwagę, którą wyraziłem kilkakrotnie i mocno w monografii. Rzecz w tym, że niezależnie od tego, czy składniki osnowy są nazwami czy predykatami zdaniotwórczymi, to gdy są użyte w schematach zaproponowanych $\mathrm{w}$ analizach, wtedy trzeba je interpretować zdaniowo, tj. jako reprezentujące ,złożone z nich" warunki/założenia pytania oraz odpowiedzi na pytanie. Jest to szczególnie ważne, gdy są interpretowane odpowiedzi przeczące oraz gdy jest oceniana trafność pytań do rozstrzygnięcia. Rozumienie w tych schematach składników jako nazw, a składników zanegowanych jako wyrażeń z negacją przednazwową skutkuje bowiem błędną interpretację odpowiedzi na pytanie i złą oceną trafności. 
Jeśli chodzi o drugą z zacytowanych wypowiedzi, to nie zgadzam się jak wskazują na to powyższe wyjaśnienia — z tym, że non to zwykła negacja przedzdaniowa; nie jest to również negacja przednazwowa ${ }^{25}$. Natomiast prawdą jest, że definicja negacji non jest ostatecznie oparta na negacji przedzdaniowej, negowana część osnowy jest bowiem reprezentowana przez alternatywę zdań, które odpowiadają kolejnym (w sumie wszystkim) możliwościom zanegowania składników danej części osnowy: składników pojedynczych, dowolnych podwójnych, dowolnych trzech, ..., wszystkich składników kwestionowanej części osnowy (w sytuacji skrajnej „negowana część” jest całą osnową).

Dla ilustracji tej i innych kwestii podjętych przez M. Lechniaka (odnoszę się tu tylko do uwag głównych) spójrzmy na przykład zdania pytajnego o osnowie zaczerpniętej z jego artykułu:

\section{(14) Czy Jan czyta książkę?}

Stosując metodę „kombinatoryczną”, można wskazać siedem opartych na tym zdaniu pytań (M. Lechniak mówi o ośmiu możliwych „rozkładach” zdania Jan czyta książkę, bo uwzględnia także samo to zdanie). Tutaj wybiorę te tylko, które dobrze ilustrują przyjęte w monografii rozumienie negacji non. Otóż gdy zdanie (14) jest odczytane np. jako pytanie:

(14a) Jan ksiażkę czy czyta?,

wtedy zgodny $\mathrm{z}(*)_{\mathrm{R}}$ schemat tego pytania, $\mathrm{tj}$.

$? x \in\{\{\mathrm{c}\}$, non $\{\mathrm{c}\}\}:\{\mathrm{J}, \mathrm{K}\}(\{x\})$,

wyznacza formuły dla odpowiedzi właściwych:

twierdzącej $=\{\mathrm{J}, \mathrm{K}\}(\{\mathrm{c}\})$ oraz przeczącej $=\{\mathrm{J}, \mathrm{K}\}($ non $\{\mathrm{c}\})$.

${ }^{25} \mathrm{~W}$ monografii jest skrupulatnie odróżniany skrót negacji non, tj. zapisana kursywą litera $n$ — od symbolu negacji przednazwowej (litera n zapisana bez kursywy), ponadto skróty nazw, tj. symbole stałych są pisane drukiem zwykłym (litery duże dla nazw, małe dla funktorów zdaniotwórczych), a symbole zmiennych są zapisywane kursywą. We fragmentach artykułu M. Lechniaka streszczających i omawiających odróżnienia te nie są konsekwentnie stosowane, co może prowadzić do złego odczytania i niezrozumienia rozwiązań zaproponowanych w monografii. Na przykład formuły widoczne w artykule na s. 296, tj.:

$\{s, F\}(n A) \Leftrightarrow\{x:\{s, F\}(x)\} \neq \varnothing \wedge n A \in\{x:\{F, s\}(x)\}$

$\{s, F, \mathrm{n}(n A)\} \Leftrightarrow\{x:\{s, F\}(x)\} \neq \varnothing \wedge n A \notin\{x:\{F, s\}(x)\}$

powinny być (i są w monografii) zapisane tak:

$\{\mathrm{s}, \mathrm{F}\}(\mathrm{nA}) \Leftrightarrow\{x:\{\mathrm{s}, \mathrm{F}\}(x)\} \neq \varnothing \wedge \mathrm{nA} \in\{x:\{\mathrm{F}, \mathrm{s}\}(x)\}$

$\{\mathrm{s}, \mathrm{F}, n(\mathrm{nA})\} \Leftrightarrow\{x:\{\mathrm{s}, \mathrm{F}\}(x)\} \neq \varnothing \wedge \mathrm{nA} \notin\{x:\{\mathrm{F}, \mathrm{s}\}(x)\}$. 
W formułach tych napis „\{J, K $\}$ ” nie oznacza zbioru, którego elementami są nazwy Jan oraz Kolumb (nazwy te są składnikami osnowy rekonstruowanego pytania), lecz oznacza warunek tego pytania, głoszący, że jest jakiś związek między Janem a książką. W języku teoriomnogościowym jest to warunek niepustości zbioru relacji wiążących Jana z książką, a wyrażona w tym języku odpowiedź twierdząca głosi, że elementem tego zbioru jest relacja czytania (przez Jana książki), co w języku naturalnym znaczy, że Jan książę czyta. Odpowiedź przecząca głosi, że Jan książki nie czyta, czyli że czytanie nie jest elementem tego zbioru; a nie, że zachodzi jakiś inny związek między Janem a książką (np. relacja przeglądania, pisania, poprawiania etc.).

Aby lepiej zilustrować różnicę między non a negacją przednazwową, rozważmy pytanie:

\section{Jan czyta czy książkę?}

Warunek $\{\mathrm{J}, \mathrm{c}\}$ tego pytania w języku naturalnym brzmi Jan (coś) czyta, a w niesymbolicznym języku teorii zbiorów: niepusty jest zbiór obiektów, o których można prawdziwie orzec, że są czytane przez Jana. Odczytanie schematu odpowiedzi twierdzącej jest oczywiste:

$\{\mathrm{J}, \mathrm{c}\}(\{\mathrm{K}\})=$ Jan czyta książke.

W schemacie dla odpowiedzi przeczącej, tj. w:

$\{\mathrm{J}, \mathrm{c}\}($ non $\{\mathrm{K}\})$, a w krótszym zapisie $\mathrm{w}\{\mathrm{J}, \mathrm{c}\}(n \mathrm{~K})$,

symbol $n$ nie jest negacją przednazwową, co znaczy, że „, $n \mathrm{~K}$ ” nie jest zaprzeczeniem nazwy $\mathrm{K}$, którego zakresem jest dopełnienie zakresu nazwy $\mathrm{K}$ do uniwersum obiektów, które mogą być czytane. W kontekście schematu odpowiedzi na pytanie (14b) symbol $n \mathrm{~K}$ musi być interpretowany jako twierdzenie, że książka nie jest czytana przez Jana, czyli nie należy do zbioru obiektów, o których można zgodnie z prawdą orzec, że są czytane przez Jana; odpowiedzi przeczącej nie można zatem odczytać jako: Jan czyta nieksiążkę, czyli czyta coś innego niż książkę ${ }^{26}$.

\footnotetext{
${ }^{26} \mathrm{~W}$ monografii wielokrotnie podkreślałem potrzebę takiego odczytywania symboli poprzedzonych non (lub skrótem n), np. „Odkrył Amerykę nKolumb” = Ameryki nie odkrył Kolumb, a nie Amerykę odkryt ktoś inny; Odkrył Kolumb nAmerykę = Kolumb nie odkryt Ameryki (Ameryka nie należy do lądów odkrytych przez Kolumba), a nie Kolumb odkrył coś innego (inny lad) itd. Inne interpretowanie takiej negacji w odpowiedziach naturalnojęzykowych, tj. jako negacji przednazwowej, skutkuję błędną oceną prawdziwości założeń i trafności pytań (zob. np. KoJ 1989, 33-60-49-50).
} 
Dla uwyraźnienia różnicy między negacją przedzdaniową , negacją non i negacją przednazwową są w monografii analizowane również takie pytania, w których osnowie jest składnik poprzedzony negacją zwykłą. Niech przykładem takiego zdania pytajnego będzie tu:

$$
\text { Czy Jan czyta nie-książkę. }
$$

By ułatwić porównanie z pytaniem (14b), rozważmy odpowiedź właściwą przeczącą na pytanie:

$$
\text { Jan czyta czy nie-ksiażkę? }
$$

Schematy odpowiedzi właściwych to:

$\{\mathrm{J}, \mathrm{c}\}(\{\mathrm{nK}\})$ oraz $\{\mathrm{J}, \mathrm{c}\}(n\{\mathrm{nK}\})$.

W obu tych formułach litera „n” (bez kursywy) jest symbolem negacji przednazwowej, dlatego symbol „nK” oznacza ogół nadających się do czytanie nie-książek. Natomiast widoczny w drugiej formule symbol $n$ jest skrótem negacji non.

W języku rachunku zbiorów odpowiedzi te można rozwinąć następująco $^{27}$ :

$\{\mathrm{J}, \mathrm{c}\}(\{\mathrm{nK}\}): \quad\{x:\{\mathrm{J}, \mathrm{c}\}(x)\} \neq \varnothing \wedge \mathrm{nK} \in\{x:\{\mathrm{J}, \mathrm{c}\}(x)\}$,

$\{\mathrm{J}, \mathrm{c}\}(n\{\mathrm{nK}\}): \quad\{x:\{\mathrm{J}, \mathrm{c}\}(x)\} \neq \varnothing \wedge \mathrm{nK} \notin\{x:\{\mathrm{J}, \mathrm{c}\}(x)\}$.

W obu tych interpretacjach, by nie zmieniać notacji, zastosowałem taki sam sposób i schemat zapisu odpowiedzi, jak dla pytań, które nie mają w osnowie składnika $\mathrm{z}$ negacją porzednazwową ( $\mathrm{z}$ tego samego powodu również w monografii nie zmieniałem zapisu takich pytań). Ponieważ nK jest zbiorem, więc można mieć uzasadnione zastrzeżenia („Sformułowanie to wydaje się dziwne ...”) do użycia w tym napisie po „nK” symbolu $\in$ lub $\notin$. Zastrzeżenie to byłyby uzasadnione, gdyby zapisowi temu nie towarzyszyła (sformułowana w tekście głównym monografii) uwaga wyjaśniająca, że napis taki jak tu: , $\mathrm{nK} \in\{x:\{\mathrm{J}, \mathrm{c}\}(x)\}$ ” jest skrótem pełniej zapisanego wyrażenia, w którym jest użyty kwantyfikator szczegółowy, a ,nK $\notin\{x:\{\mathrm{J}, \mathrm{c}\}(x)\}$ ” jest skrótem notacji z kwantyfikatorem ogólnym. Chodzi o formuły (w monografii pominięte): $(\bigvee y)[y \in \mathrm{nK} \wedge y \in\{x:\{\mathrm{J}, \mathrm{c}\}(x)\}]$, co można wyrazić także napisem, w którym kwantyfikator ponownie jest domyślny: $\mathrm{nK} \cap\{x$ : $\{\mathrm{J}, \mathrm{c}\}(x)\}) \neq \varnothing$; oraz o zapis $(\bigwedge y \in \mathrm{nK})[y \notin\{x:\{\mathrm{J}, \mathrm{c}\}(x)\}]$ albo równo-

\footnotetext{
${ }^{27}$ Zapis w języku teoriomnogościowym, ponieważ jedna $\mathrm{z}$ uwag dotyczy zastosowanej w monografii notacji.
} 
ważnie (nK $\cap\{x:\{\mathrm{J}, \mathrm{c}\}(x)\})=\varnothing$ (te alternatywne sposoby zapisu są wskazane w przypisie w JANKISZ 2020b, 133).

W kontekście tych pełniej zapisanych drugich członów koniunkcji widać także wyraźniej, że nie jest trafna sugestia, by posłużyć się relacją inkluzji. Zastąpienie symboli $\in \mathrm{i} \notin$ symbolami, odpowiednio, $\subset$ oraz $\not \subset$ skutkuje błędną interpretacją odpowiedzi — co rażąco widoczne, jeśli pytanie (15a) jest rozumiane jako odnoszące się do konkretnej sytuacji, tj. do tego, czy Jan tu i teraz czyta nie-książkę (czy to, co czyta, jest czymś innym niż książka), lecz także, gdy jest odczytywane generalnie. Warunek $\mathrm{nK} \subset\{x:\{\mathrm{J}, \mathrm{c}\}(x)\}$ jest za mocny, wymaga bowiem, by Jan czytał wszystko inne (wszystkie nieksiążki), a warunek $\mathrm{nK} \not \subset\{x:\{\mathrm{J}, \mathrm{c}\}(x)\}$ jest za słaby, bo jest spełniony, gdy choć jeden niebędący książką obiekt nie jest przez Jana czytany (czyli w rzeczywistych sytuacjach warunek ten jest spełniony zawsze).

\section{B.3 Metody filozoficzne}

Profesor Anna Brożek pyta: Jakie metody stosowane są w filozoficznych i logicznych koncepcjach pytań? i stawia w kontekście tego pytania hipotezę, że są to metody analizy, parafrazy i aksjomatyzacji. Pytanie to jest uszczegółowieniem problemu wskazanego tytułem B3: Jakie są metody stosowane w filozofii? Nie potrafię, nie tylko w niniejszym tekście, powiedzieć na ten temat niczego oryginalnego. Mogę jedynie, w sposób bardzo stronniczy, wskazać ogólnie ten sposób filozofowania, który najbardziej cenię. Chodzi o filozofię racjonalistyczną, a zwłaszcza o wspartą na logice, oraz filozofię otwartą na wyniki nauk, zwłaszcza nauk fizykalnych. Znaczy to, że nie cenię (mogę wyznać, że z trudem znoszę) filozofowania, którego wyniki nie nadają się do dyskusji, a zwłaszcza takiego, które programowo odcina się od wzorców poprawności wskazanych przez logikę oraz od wyników nauk ważnych dla podejmowanych zagadnień filozoficznych ${ }^{28}$.

Dzielenie się ,przekonaniami metodologicznymi leżącymi u podstaw [mojej] teorii pytań i odpowiedzi” rozpocznę zatem od stwierdzenia, że moje podejście w tej dziedzinie jest zgodne $\mathrm{z}$ wyżej wyróżnionym sposobem filozofowania. W podejściu tym mieści się badanie prowadzone zgodnie ze schematem: analiza — parafraza — aksjomatyzacja. Do „analizy” odniosę się odrębnie, teraz natomiast uwagi co parafrazy i aksjomatyzacji.

\footnotetext{
${ }^{28}$ Decydujący wpływ na takie metafilozoficzne wartościowania miało środowisko filozoficzne, a zwłaszcza - w okresie moich studiów — działalność filozoficzna i nauczycielska ks. prof. Stanisława Kamińskiego, prof. Antoniego B. Stępnia oraz ks. prof. Stanisława Mazierskiego, a później — prof. Leona Koja.
} 
Metoda parafrazowania jest skuteczna wtedy, gdy w analizach filozoficznych dokonuje się przekładania na bieżąco i obustronnego. Chodzi o to, że dane wyrażenia, na przykład sformułowane w języku naturalnym zdania pytajne i odpowiedzi, powinny być nie tylko w punkcie wyjścia analizy filozoficznej przekładane na język, w którym da się zastosować do nich ścisłe pojęcia i metody dowodowe (na przykład teoriomnogościowe), lecz i o to, by uzyskane wyniki, sformułowane w języku ścisłym, były na bieżąco przekładane na język wyjściowy, a przekłady były konfrontowane $\mathrm{z}$ tym, co w badanej dziedzinie, np. w praktyce stawiania pytań i odpowiadania, jest oczywiste, wiadome, uznane - jest dane niezależnie od analiz filozoficznych.

Opowiadam się więc w filozofii w ogóle i w filozoficznym badaniu pytań i odpowiedzi za metodą (quasi-)empiryczno-dedukcyjną, którą znam m.in. z metaetycznych postulatów Tadeusza Czeżowskiego oraz jego prac etycznych i tzw. logiki dóbr, w których postulaty te są spełniane. Przedmiotowym, empirycznym źródłem koncepcji etycznej tak budowanej mają być fakty czerpane z dziedziny moralności, tj. obserwowane czyny, a zwłaszcza formułowane $\mathrm{w}$ języku naturalnym oceny poszczególnych czynów i oparte na nich ogólne normy funkcjonujące w tej dziedzinie. W budowanej na tej podstawie teorii przyjmuje się etyczne parafrazy ocen i norm moralności sformułowane w języku analiz, tj. języku mieszanym, czasami sztucznym. Koncepcja (teoria) etyczna jest budowana metodą analizy pojęć etycznych oraz badania relacji między pojęciami i twierdzeniami etycznymi. Z kolei konsekwencje teorii, tj. wyprowadzone z jej norm ogólnych normy i oceny szczegółowe są konfrontowane $\mathrm{z}$ faktami, tj. ze zdaniami opisującymi czyny i ocenami czynów formułowanymi w dziedzinie moralności. Wynikiem konfrontacji może być korekta, a nawet eliminacja norm teorii etycznej.

Jeśli chodzi o aksjomatyzację, to gdy jest ona rozumiana tak, jak w naukach dedukcyjnych, wtedy - jak wiadomo i co jest zgodne $\mathrm{z}$ uwagami A. Brożek - zwykle jest jedynie wzorcem, do którego może się zbliżać porządkowanie pojęć i twierdzeń składających się na koncepcję filozoficzną. Zmierzanie do tego wzorca wymaga ścisłego zdefiniowania pojęć podstawowych budowanej koncepcji filozoficznej oraz wykrywania i - na ile się da - dowodowego okazywania związków logicznych między jej twierdzeniami. Jednakże ścisłość nie wymaga używania języka symbolicznego (nie mówiąc o sformalizowanym), co więcej - używanie takiego języka często utrudnia śledzenie rozważań i zrozumienie ich wyników, a bywa i tak, że przesłania, maskuje nieścisłe pojęcia i nietrafne twierdzenia.

Co się natomiast tyczy analizy, to chciałbym rozpocząć od odniesienia się do charakterystyki etapów metody opisu analitycznego zawartej w artykule 
A. Brożek. Pierwsza uwaga jest uzupełniająca: perspektywę teoretyczną badań wyznacza nie tylko wybór dziedziny i dostosowanie się do zastanej siatki pojęciowej, lecz także postawione problemy i wyniki uzyskane w różnych, często konkurencyjnych ujęciach filozoficznych. Uwagi nie tylko uzupełniające mam do wyboru "egzemplarza modelowego (resp. egzemplarzy modelowych)” wedle jego „prostoty i reprezentatywności”. Otóż kryterium reprezentatywności zakłada, jak sądzę, ujęcie istoty gatunkowej (dlatego uwaga ta dotyczy również etapu trzeciego, tj. istotnościowego opisu egzemplarza modelowego). Egzemplarz reprezentatywny, typowy to wszak taki, który na pewno zachowuje, a ponadto wyraźnie przejawia cechy istotne dla gatunku. Pogląd ten jest zgodny z uwagą metodologiczną L. Koja, którą sformułował we wprowadzeniu do swojej teorii znaków: w jej punkcie wyjścia jest już jakaś preteoria znaku, określająca zakres badanej dziedziny, tj. to, co zamierzona teoria znaków ma objąć (opisać, wyjaśniać). Wysłowienie takiej prekoncepcji, a składa się na nią także założenie co do uniwersum badanych obiektów, szkicuje już pewne cechy zamierzonego ujęcia, tj. wybór metody, a także treść (twierdzenia) zamierzonej koncepcji. Nawet za ogólną deklaracją, że zamiarem jest zbudowanie teorii, którą da się stosować do ogółu obiektów - na przykład ogółu pytań i odpowiedzi funkcjonujących w sytuacjach pytajnych albo do wszystkich faktycznie używanych znaków — są ukryte założenia co do zakresu podstawowych pojęć teorii, która ma być zbudowana ${ }^{29}$.

Do „sformułowania hipotezy definicyjnej” mam jedynie tę uwagę, że „podniesienie opisu do rangi definicji/zasady” nie wyklucza eliminacji (mówienie o „falsyfikacji” zakłada, że definicje mają wartość logiczną); chodzi raczej o to, że uznawanie zaproponowanej definicji wyklucza jej jednoczesne odrzucanie, lecz nie wyklucza jej testowania, sprawdzania (etap piąty), które może się zakończyć jej odrzuceniem, wskutek niezgodności z innymi uznanymi założeniami teoretycznymi (,perspektywą teoretyczną” lub odnośnymi twierdzeniami z „korpusu werbalnego”) lub z ,instancjami pojęcia” wyjściowymi (składającymi się na „korpus empiryczny”) lub odkrytymi w trakcie sprawdzania definicji. Ostatnia uwaga dotyczy związku metody analizy i wyróżnionych jej etapów z metodami parafrazy i aksjomatyzacji $\mathrm{i}$ jest zgodna $\mathrm{z}$ wyrażoną przez A. Brożek: metoda opisu analitycznego powinna być stosowana również $\mathrm{w}$ trakcie parafrazowania, a także na etapie porządkowania pojęć i twierdzeń teorii.

\footnotetext{
${ }^{29}$ Leon Koj wskazuje przykłady dziedzin, które ma objąć budowana przez niego, ogólna koncepcja znaku (Kos 1998, 27). Do uwagi L. Koja o takich prototeoretycznych założeniach miałem sposobność odnieść się w artykule JoNKISZ 2016, 39-56.
} 
Ważniejsze od powyższych uwag jest jednak dla mnie to, że sposób filozofowania, który cienię najwyżej i starałem się stosować w rozważaniach przedstawionych $\mathrm{w}$ monografii, jest zbieżny z wzorcem filozofowania scharakteryzowaną przez A. Brożek. Wyróżnione w tej charakterystyce metody składowe - tj. opis analityczny, parafrazowanie i aksjomatyzacja (rozumiana w sposób wyjaśniony) - są w monografii obecne, choć nie potrafiłbym ich tak trafnie jak A. Brożek wydzielić i opisać. Na pewno jest w monografii wyraźnie widoczny „korpus empiryczny”, czyli zasób analizowanych zdań pytajnych, w trakcie analiz stopniowo powiększany i różnicowany. Korzystałem z niego i na etapie formowania podstawowych pojęć mojej koncepcji, jak i - a nawet zwłaszcza wtedy, gdy jej definicje i twierdzenia były sprawdzane. Dobrym tego przykładem były wątpliwości (nadal nie do końca odsunięte) co do sposobu interpretowania w języku teorii mnogości odpowiedzi na pytania do rozstrzygnięcia. Poszukiwanie właściwego rozwiązania skłoniło nie tylko do zastosowania w analizach pojęcia negacji non, lecz także do wielokrotnego i żmudnego sprawdzania różnych możliwości, na drodze oceny i porównywania wyników ich stosowania do zróżnicowanego „materiału empirycznego" dobieranego tak, by testy były surowe. Przyjęcie w definicji negacji non alternatywy zwykłej (warunku: co najmniej jedno zdanie spośród ...) jest według mnie zgodne nie tylko z negowaniem koniunkcji (reprezentującej odpowiedź twierdzącą), lecz prowadzi do uzyskania takich formuł dla odpowiedzi przeczących, które (ich przekłady) są zbieżne $\mathrm{z}$ rozumieniem takich odpowiedzi formułowanych $\mathrm{w}$ języku naturalnym. Ta zgodność skłoniła mnie do przyjęcia takiej właśnie definicji, definicja z alternatywą rozłączną — choć prowadzi do wyników wyglądających lepiej w języku teoriomnogościowym - wymusza bowiem interpretację odpowiedzi zbyt mocną w kontekście języka naturalnego, tj. rozumienia pytań i odpowiedzi w rzeczywistych sytuacjach.

O skuteczności metod zastosowanych w monografii świadczą także wyniki uzyskane w takim ujęciu problematyki pytań i odpowiedzi. Zaproponowane w monografii schematy struktury da się stosować do dowolnych pytań, także do uznanych za „trudne” do analizowania, a do podziału pytań uzasadnionego w monografii można sprowadzić kategorie wyróżniane w innych podziałach. Schematy te są również skuteczne w badaniu trafności pytań (także do porównywanie różnych koncepcji trafności) oraz w wyróżnianiu i interpretowaniu odpowiedzi na pytania. Stosowanie metody analitycznej, „składnikowo-kombinatorycznej” doprowadziło również do zaproponowania nowych, ścisłych kryteriów podziału odpowiedzi na właściwe/ 
niewłaściwe, dorzeczne/niedorzeczne, pełne/niepełne (w nich - częściowe), wprost/niewprost (podział skuteczny w obrębie każdej z inaczej wyróżnionych kategorii odpowiedzi) oraz adekwatnych/nieadekwatnych.

$\mathrm{Na}$ tle wzorca opisanego przez A. Brożek jest jednak w monografii wyraźnie widoczna luka: brak w niej niemalże zupełnie „korpusu werbalnego", zwłaszcza - teoretycznego, tj. brak odniesień do innych koncepcji erotetycznych, także odniesień porównawczych. Ograniczenie to było częściowo wymuszone przez okoliczności towarzyszące budowaniu koncepcji pytań i odpowiedzi (wspomniałem o nich w monografii), zgadzam się jednak $\mathrm{z}$ oceną, że luka ta powinna być przynajmniej częściowo wypełniona, a tym bardziej z oceną, wyrażoną przez J. Wojtysiaka, że jest bardzo potrzebne opracowanie historii polskiej erotetyki.

\section{BIBLIOGRAFIA}

Ajdukiewicz, Kazimierz. 1975. Logika pragmatyczna. Warszawa: Państwowe Wydawnictwo Naukowe.

Brożek, Anna. 2008. Pytania i odpowiedzi. Analiza krytyczna koncepcji Kazimierza Ajdukiewicza, „Zagadnienia Filozoficzne w Nauce” 42 (2008):147-152.

BrożeK, Anna. 2007. Pytania i odpowiedzi. Tło filozoficzne, teoria, zastosowania praktyczne. Warszawa: Wydawnictwo Naukowe Semper.

BrożeK, Anna. 2021. „Pytania w opisie analitycznym. Logika erotetyczna z metodologicznego punktu widzenia". Roczniki Filozoficzne 69, nr 4: 259-280 (tekst z tego numeru $R F$ ).

JADACKI, Jacek. Spór o granice języka. Elementy semiotyki logicznej i metodologii. Warszawa: Wydawnictwo Naukowe Semper.

JoNkIsz, Adam. 2019. „Wieloznaczność zdań pytajnych”. Filozofia Nauki nr 4: 115-134.

JoNkIsZ, Adam. 2020. „Struktura pytań”. Filozofia Nauki nr 1: 25-60.

JonkIsz, Adam. 2020. Pytania i odpowiedzi. Ujęcie teoriomnogościowe, Kraków: Wydawnictwo Naukowe Akademii Ignatianum w Krakowie.

Jonkisz, Adam. 2016. O wyrażeniach i nazwach. „Studia z Filozofii Polskiej” 11: 39-56.

KoJ, Leon. 1998. „Próba zdarzeniowej teorii znaku”. Studia Semiotyczne 21-22: 27-46.

KoJ, Leon. 1989. „Inquiry into the Structure of Questions”. W: Inquiries into the Generating and Proper Use of Questions, red. Leon Koj i Andrzej Wiśniewski, 33-60. Lublin: Wydawnictwo Uniwersytetu Marii Curie-Skłodowskiej.

LeChNiaK, Marek. 2021. „Czy da się pominąć ontologię? Uwagi na marginesie Pytań i odpowiedzi Adama Jonkisza". Roczniki Filozoficzne 69, $\mathrm{nr}$ 4: 281-303 (tekst z tego numeru RF).

WoJTysiak, Jacek. 2021. „Kilka wątpliwości co do Adama Jonkisza teorii pytań”. Roczniki Filozoficzne 69, $\mathrm{nr}$ 4: 305-314 (tekst z tego numeru $R F$ ). 


\section{LOGICZNE UJĘCIE PYTAŃ I ODPOWIEDZI. UWAGI MERYTORYCZNE I METODOLOGICZNE}

\section{Streszczenie}

W artykule odnoszę się do wypowiedzi Anny Brożek, Marka Lechniaka i Jacka Wojtysiaka, sformułowanych w dyskusji nad monografią Pytania i odpowiedzi. Ujęcie teoriomnogościowe. Zawarte $\mathrm{w}$ artykule odpowiedzi są podzielone na merytoryczne i metodologiczne, odpowiednio do tego, czy sformułowane w tych wypowiedziach komentarze i propozycje ulepszeń odnoszą się do zaproponowanej w monografii koncepcji, czy do stosowanych w niej metod jej budowania.

W uwagach merytorycznych odpowiadam na kwestie związane ze strukturą, rodzajami i trafnością pytań. Argumentuję, że: (i) zaproponowane w monografii schematy struktury pytań są takim rozwinięciem tzw. schematu polskiego, które daje możliwość ukazania i usunięcia wieloznaczności dowolnych zdań pytajnych i opartych na nich pytań; (ii) choć ogólny schemat struktury jest wspólny dla wszystkich pytań, to przyjęte w monografii podziały pytan - a zwłaszcza na pytania do rozstrzygnięcia i pozostałe - są merytorycznie uzasadnione i logicznie poprawne; (iii) trafne są twierdzenia dotyczące związków między trafnością pytań a prawdziwością ich założeń, choć ogólne wnioskowanie od prawdziwości założeń do trafności pytań problemowych wymaga (zgodnie $\mathrm{z}$ uwagą J. Wojtysiaka) dodatkowego warunku.

Uwagi metodologiczne dotyczą tzw. składnikowo-kombinatorycznej metody analizowania pytań, pojęcia tzw. uogólnionej negacji oraz oceny metod filozofowania widocznych w monografii na tle metody wzorcowej (opisanej przez A. Brożek). Okazuję, że: (iv) stosowana w monografii metoda reprezentowania i analizowania zdań pytajnych daje narzędzie do wyróżniania wszystkich ich możliwych znaczeń (możliwych pytań), co w rekonstruowaniu sytuacji pytajnych zawęża analizy do pytań zgodnych z regułami języka (wyklucza konstruowanie zestawień bezsensownych, przed którymi ostrzega M. Lechniak), a z drugiej strony dopuszcza, że spośród ogółu możliwych są uwzględniane tylko pytania w danej sytuacji aktualne; (v) negacja non, choć jest ostatecznie oparta na negacji przedzdaniowej (jest zdefiniowana przez alternatywę $\vee$ i negację $\sim$ ), to jest jej uogólnieniem, ponieważ może być stosowana nie tylko do całej osnowy p pytania "Czy p?", lecz także do jej dowolnych członów, aż do pojedynczych składników, a przy tym jest równoważnie wymienna $\mathrm{z}$ negacją $\sim \mathrm{w}$ sytuacji negowania całej osnowy p; (vi) sposób filozofowania, który zastosowałem w monografii, jest zgodny z metodą łączącą analizowanie, parafrazowanie i aksjomatyzację, choć daleko mu zwłaszcza do wzorcowej aksjomatyzacji oraz wymaga uzupełnienia w zakresie tzw. teoretycznego „korpusu werbalnego”, tj. odniesień do innych koncepcji pytań i odpowiedzi.

Słowa kluczowe: składnikowo-kombinatoryczna metoda analizowania pytań; metoda parafrazowania; uogólniona negacja; struktura pytań; rodzaje pytań; trafność pytań.

\section{THE LOGICAL CONSTRUAL OF QUESTIONS AND ANSWERS: SUBSTANTIVE AND METHODOLOGICAL REMARKS}

\section{S u m m a r y}

In this article I address the contributions of Anna Brożek, Marek Lechniak and Jacek Wojtysiak as formulated in the course of their discussion of my monographic study Pytania i odpowiedzi. Ujęcie teoriomnogościowe [Questions and answers: A Set-theoretic approach]. My responses in the article are divided into substantive and methodological ones, depending on whether the comments and suggestions for improvement formulated in their contributions refer to the actual conception proposed in the book or to the methods used in its construction. 
In my substantive comments, I respond to issues relating to the structure, types and accuracy of questions. I argue that: (i) the schematisations of question structure proposed in the monograph are a development of the so-called "Polish schema" that is such as to make it possible to exhibit and remove the elements of ambiguity in any interrogative sentences and questions based on them; (ii) although the general schematic structure is common to all questions, the division of questions adopted in the monograph — especially into questions to be resolved and others - is substantively justified and logically correct; (iii) the claims put forward regarding the relations between the accuracy of questions and the truth of their assumptions are correct - even though a general inference to the accuracy of the questions at issue from the truth of their assumptions requires (as J. Wojtysiak has observed) an additional condition to be met.

My methodological remarks concern the so-called component-combinatorial method of analysing questions, the notion of so-called "generalised negation", and the evaluation of the philosophical methods on display in the monograph in the light of the relevant model of the philosophical method (as described by A. Brożek). I show that: (iv) the method of representing and analysing interrogative sentences used in the monograph provides a tool for distinguishing all of their possible meanings (possible questions), which in the reconstruction of question situations narrows down the analyses to questions that comply with the rules of language (excluding as it does the construction of meaningless combinations, as warned against by M. Lechniak), while on the other hand enabling it to be the case that out of the total number of possible ones, only questions relevant in a given situation are taken into account; (v) the negation non, though ultimately based on propositional negation $\sim$ (it is defined by disjunction $\vee$ and negation $\sim$ ), is its generalisation, since it can be applied not only to the whole matrix p of the question "Is it the case that p?", but also to any of its parts, right down to its individual components, and at the same time is equivalently replaceable with $\sim$ in the situation of negation of the entire matrix p; (vi) the mode of philosophising that I have employed in the monograph is consistent with a method combining analysis, paraphrasing, and axiomatisation, even if it is far removed from model axiomatisation especially, and needs further completion in respect of the so-called theoretical "verbal corpus" - i.e. in terms of the references it makes to other conceptions of questions and answers.

Keywords: component-combinatorial method of question analysis; paraphrasing method; generalised negation; schematic question structure; types of questions; accuracy of questions.

Information about the Author: Prof. Dr. habil. ADAm JonkIsZ - Jesuit University Ignatianum in Krakow, Faculty of Philosophy, Institute of Philosophy, Department of Logic, Epistemology and Philosophy of Science; correspondence address: ul. Kopernika 26, 31-501 Kraków; e-mail: adam.jonkisz@ignatianum.edu.pl; ORCID: https://orcid.org/0000-0001-9850-2137. 